
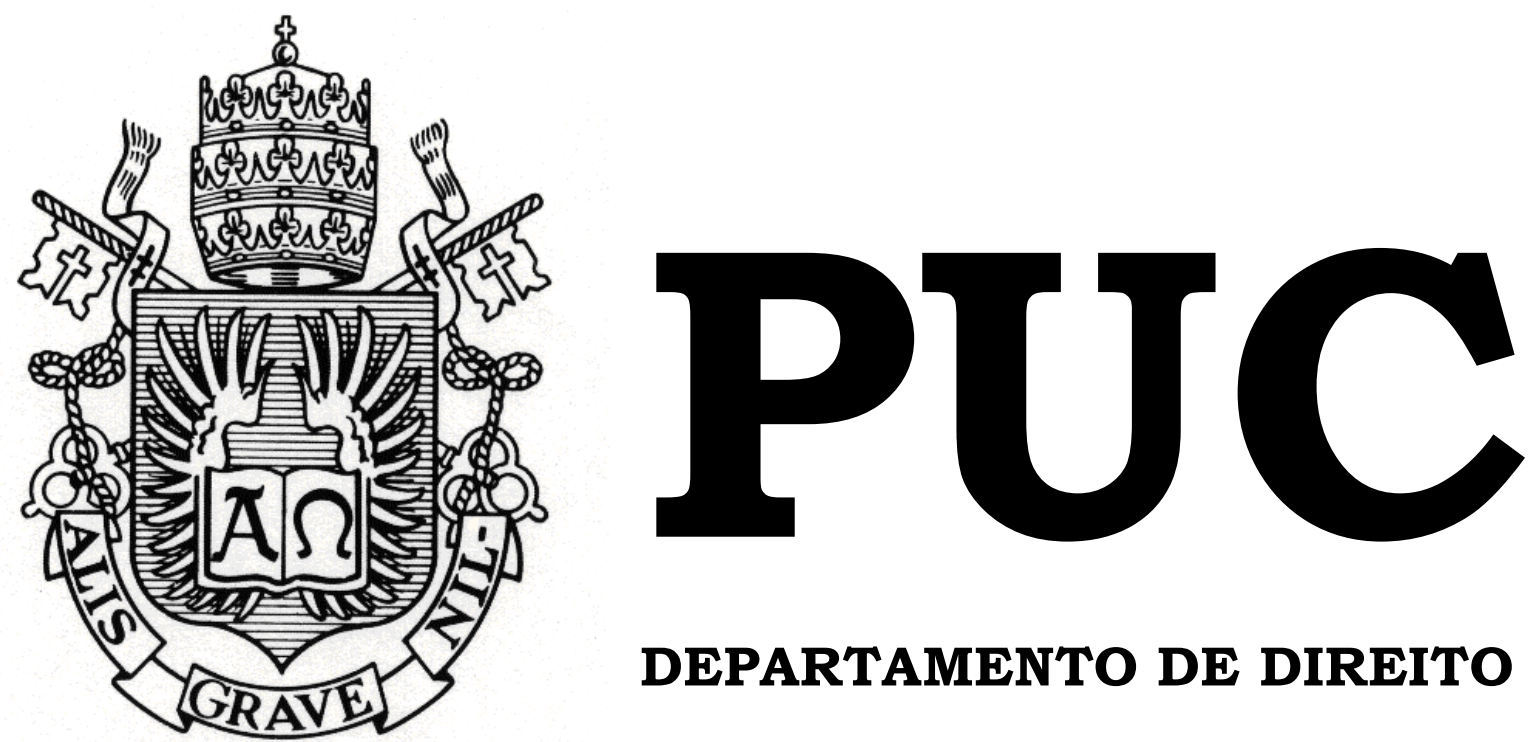

DEPARTAMENTO DE DIREITO

\title{
LIMITES AO PODER SANCIONADOR DA COMISSÃO DE VALORES MOBILIÁRIOS
}

por

SOFIA TEVES GRÜNEWALD

ORIENTADOR: JULIAN FONSECA PEÑA CHEDIAK

2019.2

PONTIFÍCIA UNIVERSIDADE CATÓLICA DO RIO DE JANEIRO RUA MARQUÊS DE SÃO VICENTE, 225 - CEP 22453-900 RIO DE JANEIRO - BRASIL 


\title{
LIMITES AO PODER SANCIONADOR DA COMISSÃO DE VALORES MOBILIÁRIOS
}

\author{
por
}

\section{SOFIA TEVES GRÜNEWALD}

Monografia apresentada ao Departamento de Direito da Pontificia Universidade Católica do Rio de Janeiro (PUC-Rio) para a obtenção do Título de Bacharel em Direito.

Orientador: Julian

Fonseca Peña Chediak 


\section{AGRADECIMENTOS}

A minha jornada na graduação começou antes da faculdade de direito, pois iniciei minha trajetória no ensino superior no curso de comunicação da Puc-Rio. A mudança para o direito ocorreu após 2 anos de faculdade de comunicação cursados. Durante todo esse período de incertezas, meus pais, Bernardo e Ana Julia, e minha irmã Catarina, foram o suporte que eu precisava para me sentir segura e seguir em frente. A eles, dedico não só este trabalho, como também todas as minhas vitórias, pois sem eles nenhuma delas seria possível. Obrigada aos três pelo genuíno interesse na minha formação e no meu trabalho, pelas longas conversas sobre o direito e tantos outros temas e pelo incansável apoio, fundamentais para o meu crescimento e para a conclusão do curso de direito e desta monografia.

A minha avó, Ecila, uma das pessoas mais cultas e inteligentes que conheço, registro não só o meu muito obrigada, como também a minha eterna admiração. Aos 84 anos, sua avidez por novos assuntos e aprendizados é admirável. Obrigada por acompanhar de perto a minha vida e por ter participado tão fortemente da minha educação com tanto amor e zelo.

Ao meu namorado e companheiro Victor Brum, agradeço imensamente pela parceria. Obrigada pelo incentivo e suporte não só ao longo deste trabalho, mas também por todo o seu apoio durante a faculdade. Em especial, agradeço a companhia e compreensão nos finais de semana de estudos, pesquisas e produção desta monografia. Agradeço, também, sua valiosa revisão e sugestões que tanto acrescentaram a este trabalho. Você é fonte de inspiração pessoal e profissional para mim.

Ao meu orientador, mestre e chefe, Julian Chediak, muito obrigada pela generosidade de dividir comigo o seu vasto conhecimento sobre inúmeros assuntos dentro e fora do direito. Obrigada especialmente pelos grupos de estudos e pela monitoria, ocasiões em que tive oportunidades valiosas de aprender com você. Obrigada, também, pelos comentários e importantes sugestões ao presente trabalho. 
Agradeço também a todos os membros do escritório Chediak, Lopes da Costa, Cristofaro, Menezes Côrtes, Simões Advogados pelas oportunidades e pelos ensinamentos. Aos meus colegas estagiários que viraram amigos, Constança Simões Barbosa, Joana Mendes, Lucca Bruzzi, Ana Paula Rodrigues e Rafaela Marsillac, obrigada por terem feito a rotina ser mais leve ao longo desses mais de 3 anos de escritório. Ao Pedro Brigagão, amigo e ex chefe, obrigada pelas conversas sobre a Comissão de Valores Mobiliários e o mercado de capitais e especialmente pela sua leitura e comentários a este trabalho.

Por fim, agradeço às minhas queridas amigas Ana Luisa Leal, Eduarda Sisto, Mariana Castro, Paula Cruz, Renata Autran e Yanne Maia pela amizade, incentivo e parceria ao longo de tantos anos. Aos meus amigos de faculdade, Paula Trindade, Mateus Reis e Lucca Borges, obrigada pelos debates e estudos jurídicos e por todos os cafés nos Funcionários que tornaram o dia a dia ao longo desses 5 anos muito mais divertido. 


\section{RESUMO}

O presente trabalho trata sobre o poder regulatório da Comissão de Valores Mobiliários (CVM), autarquia reguladora do mercado de capitais brasileiro.

O intuito do presente trabalho é expor e analisar os poderes da autarquia (normativo, fiscalizador e o poder sancionador), especialmente o poder sancionador. Com relação a este, o trabalho analisa os limites que a autarquia encontra para sua aplicação, tanto na Constituição da República de 1988 quanto na legislação infraconstitucional. Também são apresentados outros meios de enforcement que podem ser utilizados pela autarquia na repressão ou prevenção de irregularidades.

Palavras Chave: Comissão de Valores Mobiliários - CVM - mercado de capitais - regulação - regulamentação - poder de polícia - poder sancionador - processo administrativo sancionador - PAS. 


\section{SUMÁRIO}

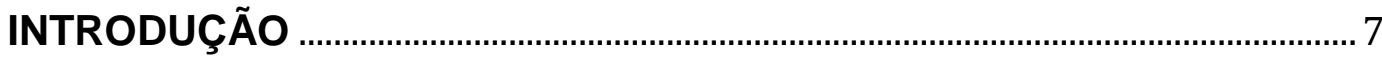

I - O DESENVOLVIMENTO DO MERCADO DE CAPITAIS BRASILEIRO

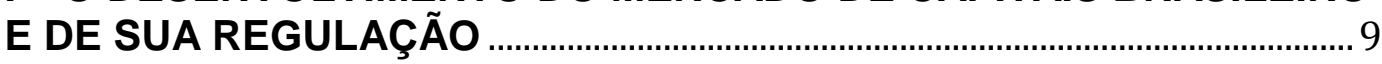

I.1. A finalidade da regulação do mercado de capitais ......................... 10

l.2. A influência da regulação do mercado de capitais norte americano

I.3. Breve histórico do mercado de capitais no Brasil e de sua regulamentação

II - OS PODERES DA COMISSÃO DE VALORES MOBILIÁRIOS............ 19

II.1. Os poderes de fiscalização e regulamentação................................. 19

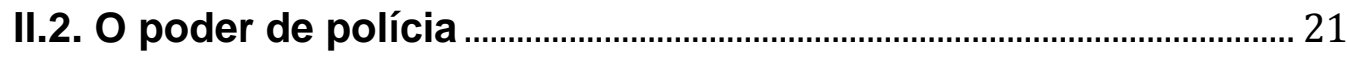

II.3. O poder sancionador ………………………………………………….... 24

II.3.1. Autonomia do poder sancionador com relação ao poder de polícia

III - O PROCESSO ADMINITRATIVO SANCIONADOR NA CVM ............. 29

III.1. Breve histórico da regulação da atividade sancionadora da CVM

III.2. O atual processo administrativo sancionador da CVM e seu

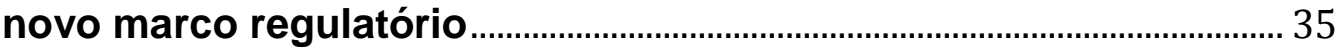

IV - LIMITES AO PODER SANCIONADOR DA CVM ……........................... 42

IV.1. Sujeitos sobre os quais incide o poder sancionador da CVM 43

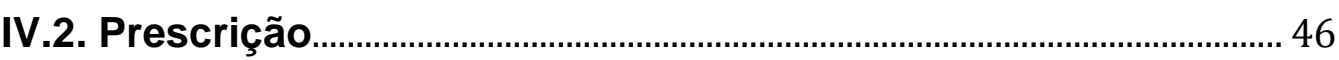

IV.3. Princípios constitucionais do direito punitivo ................................ 52

IV.4. A Lei da Liberdade Econômica ............................................................ 72

IV.5. Outros meios de exercício do poder regulador ............................. 74

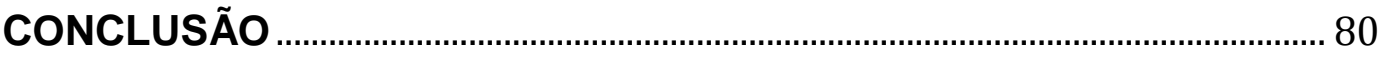

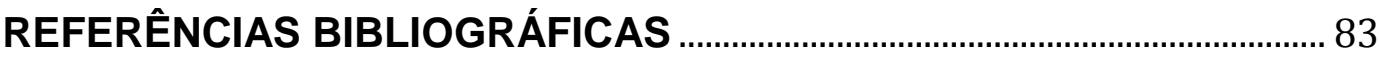




\section{LISTA DE ABREVIAÇÕES}

CVM - Comissão de Valores Mobiliários

CRSFN - Conselho de Recursos do Sistema Financeiro Nacional

ICVM nº 607 - Instrução CVM nº 607

Lei do Mercado de Capitais - Lei no 6.385/1976

Lei das Sociedades Anônimas - Lei nº 6.404/1976

PAS - Processo Administrativo Sancionador 


\section{INTRODUÇÃO}

Seja entre economistas ou juristas, é difícil encontrar consenso na doutrina quanto a definição do termo regulação. De toda sorte, é comum imputar ao termo a característica da utilização de meios jurídicos para impor limites à atuação dos agentes privados em determinado setor da economia ou da sociedade.

Para que a regulação seja eficaz, é necessário que haja uma constante fiscalização dos agentes regulados e repreensões àqueles que eventualmente descumpram as regras, com a aplicação de medidas coercitivas que os forcem a obedecê-las.

São inerentes à atividade regulatória os seguintes poderes: o poder normativo, caracterizado pela elaboração, pelo agente regulador, de normas regulamentares; o poder fiscalizador, que se refere à supervisão dos entes regulados para verificação do cumprimento da regulação; e o poder sancionador, qual seja, o poder de aplicar medidas para punir administrativamente os regulados que descumprem as referidas normas ${ }^{1}$.

$\mathrm{O}$ intuito do presente trabalho é expor e analisar os poderes da Comissão de Valores Mobiliários (CVM), autarquia de regime especial que atualmente regula o mercado de capitais brasileiro e é responsável pela sua fiscalização e regulamentação, bem como pela imposição de sanções aos agentes e participantes desse mercado. Mais especificamente, esta monografia analisará os limites que a autarquia encontra, especialmente na Constituição da República de 1988, para a aplicação de seu poder sancionador.

No capítulo I será feito um breve resumo do desenvolvimento do mercado de capitais brasileiro desde 1960, quando sua expansão começou de fato, bem como da regulação do mercado de capitais e da influência que tal

\footnotetext{
${ }^{1}$ CAVALI, Marcelo Costernaro. Fundamento e limites da repressão penal da manipulação do mercado de capitais: uma análise a partir do bem jurídico da capacidade funcional alocativa do mercado. São Paulo. 2017. 352 p. Tese (Doutorado em Direito). Programa de Pós-Graduação em Direito da Faculdade de Direito da Universidade de São Paulo. p. 92.
} 
regulação sofreu da regulação norte-americana. Também será abordada a criação da CVM e as principais funções e objetivos da autarquia.

Expostas as bases regulatórias do mercado de capitais, no capítulo II serão apresentados os poderes inerentes à CVM para em seguida expor discussão sobre a independência do poder sancionador em relação ao poder de polícia da autarquia e as consequências práticas dessa autonomia.

No capítulo III será feito um breve histórico do processo administrativo sancionador (PAS) até o momento atual, abordando especialmente os novos dispositivos introduzidos pelo novo marco legal do PAS.

Expostos os principais pontos relacionados à CVM e seus poderes, no capítulo IV serão apresentados os limites aos quais o poder sancionador da autarquia está submetido. Por fim, serão expostos outros meios de enforcement além do processo administrativo sancionador, por vezes mais justos para os regulados e mais adequados à situação de fato. 


\section{I - O DESENVOLVIMENTO DO MERCADO DE CAPITAIS BRASILEIRO E DE SUA REGULAÇÃO}

O mercado de capitais é considerado uma das subdivisões do mercado financeiro em seu sentido amplo. Grande parte da doutrina divide o mercado financeiro latu sensu nas seguintes subespécies²: (i) mercado de crédito ou mercado bancário (ou, ainda, mercado financeiro stricto sensu); (ii) mercado monetário ou aberto; (iii) mercado cambial; e (iv) mercado de valores mobiliários ou mercado de capitais ${ }^{3}$.

Em poucas palavras, o mercado de capitais pode ser definido como um ambiente em que a transferência de recursos dos agentes superavitários para os deficitários ocorre diretamente, seja entre as companhias e os investidores (mercado primário), seja entre os investidores entre si (mercado secundário). Nesse sentido, Julian Chediak explica que no mercado de capitais o acesso à poupança popular ocorre por meio de uma instituição autorizada pela CVM para realizar a mera aproximação entre os agentes - ao contrário do que ocorre no sistema financeiro stricto sensu (mercado de crédito), no qual é necessário que a instituição financeira realize a intermediação por substituição, isto é, a instituição financeira assume o lugar das partes, viabilizando a captação de recursos de seus clientes ao mesmo tempo em que concede crédito para outros ${ }^{4}$.

Nesse sentido, a regulamentação das operações no mercado de capitais visa proteger os investidores, que podem atuar diretamente no mercado e cujo acesso às informações das companhias nas quais investem é limitado ou inexistente - senão por aquilo que a própria companhia divulga. Sobre esse assunto, Julya Wellisch afirma:

\footnotetext{
${ }^{2}$ Essa divisão é didática, posto que esses mercados e seus produtos são complexos e interagem entre si.

${ }^{3}$ Tais denominações não são unânimes na doutrina, havendo divergência, inclusive, quanto à equivalência das expressões mercado de valores mobiliários e mercado de capitais. Para fins do presente trabalho, tais expressões serão usadas como sinônimos.

${ }^{4}$ CHEDIAK, Julian Fonseca da Peña. A Reforma do Mercado de Valores Mobiliários. In: Reforma da Lei das Sociedades Anônimas: inovações e questões controvertidas da Lei $\mathrm{n}^{\circ}$ 10.303, de 31.10.2001. LOBO, Jorge (coord). Rio de Janeiro: Forense, 2002. Pág. 532.
} 
"Na medida em que os valores mobiliários são bens incorpóreos, a sua verificação e avaliação ocorrem, em geral, de forma indireta, a partir de fontes produzidas pelo próprio emissor, o qual, não fosse a exigência estatal, não teria incentivos suficientes para prestar, espontaneamente, todas as informações consideradas necessárias". 5

Para que haja confiabilidade do público no mercado, é preciso que as companhias sejam obrigadas a divulgar diversas informações sobre aspectos que possam influenciar na decisão dos investidores, conferindo-lhes a possibilidade de acessar informações relacionadas tanto à própria companhia emissora, quanto à própria emissão de valores mobiliários. Conforme será explicitado a seguir, esse regime de ampla divulgação de informações é conhecido como full and fair disclosure.

Para aprofundar o tema que levará à discussão acerca do papel sancionador da CVM, convém, primeiramente, expor o processo de criação e evolução do mercado de capitais brasileiro e da base da sua regulação normativa e suas influências. É o que se passará a fazer neste capítulo.

\section{I.1. A finalidade da regulação do mercado de capitais}

Via de regra, os estados capitalistas que privilegiam a livre iniciativa pregam a liberdade de atuação dos agentes econômicos, de forma que o Estado se abstém de interferir nas atividades que tais agentes executam. A busca incessante pelo lucro tende a gerar o que os estudiosos chamam de "imperfeições no funcionamento do mercado", já que, para maximizar seus ganhos, muitos agentes agem de forma desonesta e não equitativa. Explica Luiz Leonardo Cantidiano que, regra geral, a circunstância dos mercados funcionarem de modo imperfeito não justificaria qualquer interferência do Estado para limitar a atuação dos menos éticos, uma vez que a contraparte desses agentes seria capaz de detectar os ilícitos praticados e de adotar mecanismos de defesa em face daqueles agentes ${ }^{6}$.

\footnotetext{
${ }^{5}$ WELLISCH, Julya Sotto Mayor. Mercado de Capitais: Fundamentos e Desafios. São Paulo: Quartier Latin, 2018. p. 199.

${ }^{6}$ CANTIDIANO, Luiz Leonardo. Estudos de Direito Societário. Rio de Janeiro: Renovar, 1999. p 25 .
} 
Entretanto, o mercado de capitais não implica uma relação direta entre as partes, o que geralmente impede que os agentes identifiquem os infratores a tempo de defender-se. Nesse cenário, além das enormes perdas patrimoniais a que os agentes estariam expostos, a ausência total de regulação poderia provocar um desequilibro no mercado que colocaria em risco sua credibilidade e eficiência. Assim, a regulação do mercado de capitais tem como finalidade macro proteger a economia popular e a credibilidade do mercado.

Além disso, o mercado de capitais, conforme exposto acima, faz parte do sistema financeiro nacional, que por sua vez deve estar "estruturado de forma a promover o desenvolvimento equilibrado do País e a servir aos interesses da coletividade" 7 . Com este direcionamento constitucional, "a regulação do mercado de capitais não pode deixar de ser voltada para o desenvolvimento econômico do país e outros interesses públicos" ${ }^{\text {. }}$.

Nesse sentido, o art. $4^{\circ}$ da Lei $n^{\circ}$ 6.385/1976, (cujo contexto de promulgação e principais dispositivos serão descritos a seguir) prevê como finalidades da regulação do mercado de capitais, entre outras: (i) a proteção dos investidores contra atos ilegais praticados no âmbito do mercado de valores mobiliários; (ii) evitar ou coibir modalidades de fraude ou manipulação destinadas a criar condições artificiais de demanda, oferta ou preço dos valores mobiliários negociados no mercado; (iii) assegurar o acesso do público a informações sobre os valores mobiliários negociados e as companhias que os tenham emitido; e (iv) fomentar a eficiência na alocação de capital.

\section{I.2. A influência da regulação do mercado de capitais norte americano}

Nos Estados Unidos, até o início da década de 1930, o modelo regulatório escolhido baseava-se na intervenção aplicada pelas blue sky laws,

\footnotetext{
${ }^{7}$ Art. 192 da Constituição da República de 1988.

${ }^{8}$ CAVALI, Marcelo Costernaro. Op. Cit. p. 98
} 
leis estaduais por meio das se quais conferia poder abrangente para o Estado conceder, ou não, o registro de uma emissão de valores mobiliários baseado na sua própria interpretação a respeito do investimento ${ }^{9}$. Ou seja, o Estado poderia negar uma emissão se a considerasse injusta ou não equitativa, por exemplo. Essa regulação de mérito ${ }^{10}$ se demonstrou insuficiente para proteger os investidores e o mercado da época.

Após a quebra da bolsa de valores de Nova York em 1929, o modelo de regulação do mercado de capitais americano passou por alterações. Brandeis ${ }^{11}$ (advogado norte-americano que veio a se tornar juiz da Suprema Corte daquele país) pioneiramente publicou diversos artigos na revista Harper' Weekly expondo um novo modelo de regulação, que viria a orientar a elaboração do Securities Act, de 1933, e do Securities Exchange Act, de 1934: o modelo da ampla divulgação de informações (full and fair disclosure $)^{12}$.

Tal modelo parte da premissa de que o investidor é "adulto o suficiente para, uma vez adequadamente informado, tomar as decisões econômicas que julgar mais convenientes, de acordo com o seu próprio perfil e interesse"13. Para Brandeis, não cabe à lei evitar que os investidores façam mal negócios, mas sim garantir que tenham acesso a informações verdadeiras e suficientes para avaliarem seus riscos.

\footnotetext{
${ }^{9}$ WELLISCH, Julya Sotto Mayor. Op. Cit. p. 189.

${ }^{10}$ Marcelo Trindade ressalta, ainda, o risco da regulação meritória relacionado à possíveis ações judiciais de indenização que poderiam ser movidas contra o ente estatal responsável pelo exame substancial das companhias e suas emissões. TRINDADE, Marcelo Fernandez. O papel da CVM e o mercado de capitais no Brasil. In: SADDI, Jairo (org.). Fusões e Aquisições: Aspectos Jurídicos e Econômicos, São Paulo: IOB, 2002, pp. 308-309.

${ }^{11}$ WELLISCH, Julya Sotto Mayor. Op. Cit. p. 188.

12 "Como lembram Coffee Jr. e Seligman, a legislação especial editada nos primeiros anos da Grande Depressão decorreu de duas percepções básicas. A primeira de que havia uma crise de confiança dos investidores, que se encontravam em situação de extrema vulnerabilidade diante de um mercado pouco informado e de excessivas fraudes e manipulações; e a segunda de que a Grande Depressão que se seguiu ao colapso da Bolsa de Nova York de 1929 afetou sensivelmente não apenas os participantes do mercado e a confiança dos investidores, mas também a própria economia norte-americana, gerando efeitos, portanto, para todo o país. Daí o interesse público na sua regulação que, além de assegurar a existência de um mercado íntegro, precisa proteger a confiança do investidor”. Ibid. p. 194.

${ }^{13}$ Ibid. p. 188.
} 
A atual regulação do mercado de valores mobiliários brasileiro teve nítida influência do mercado norte-americano, especialmente das mencionadas leis de 1933 e 1934. O pilar de tal sistema é a obrigatoriedade da obtenção de um duplo registro quando da emissão de valores mobiliários. O primeiro é o registro da companhia que irá emitir os valores mobiliários no órgão regulador responsável (no caso do Brasil, a CVM). O segundo registro deve ser obtido quando da emissão dos valores mobiliários, ou seja, deve haver um registro da oferta.

Esse sistema, segundo Akerlof $^{14}$, possui uma dupla função: a função interna, que corresponde a informar o investidor para que ele próprio possa tomar suas decisões de investimento e também uma função externa, qual seja, a de proteger o próprio mercado.

A seguir veremos como o mercado de capitais se desenvolveu no Brasil, bem como sua regulamentação.

\section{I.3. Breve histórico do mercado de capitais no Brasil e de sua regulamentação}

Antes da década de 1960, o mercado de capitais brasileiro praticamente não existia. A economia do país se baseava principalmente na agricultura e na exportação de produtos primários e os financiamentos dessas atividades não demandavam instrumentos muito sofisticados, sendo realizados por meio da Carteira de Crédito Agrícola do Banco do Brasil (Creai) - e, a partir de 1952, pelo BNDE - ou por meio da negociação de contratos de câmbio. Já os grandes empreendimentos eram realizados em sua maioria por empresas estrangeiras com capitais levantados no mercado inglês ${ }^{15}$.

\footnotetext{
${ }^{14}$ Economista norte-americano ganhador do prêmio Nobel. Publicou o artigo "The Market for Lemons: Quality Uncertainty and the Market Mechanism", no Quarterly Journal of Economics em 1970, no qual identificou graves problemas que afetam os mercados caracterizados por informação assimétrica.

${ }^{15}$ GALVÊAS, Ernane. O Mercado de Capitais Brasileiro. Revista de Direito Bancário e do Mercado de Capitais. vol. 41. 2008, p. 14.
} 
Além da conjuntura econômica que exigia pouco financiamento privado nacional, a crescente inflação que assolou o Brasil no final dos anos 50 e no início dos anos 60, quando o processo chegou, inclusive, à beira da hiperinflação, também freou o desenvolvimento do mercado de valores mobiliários no país. Resumidamente, pode-se dizer que a inflação foi provocada pelo elevado déficit público que os pesados investimentos em infraestrutura realizados pelo governo de Juscelino Kubitschek ao longo da década de 50 geraram. Outra forte barreira para o desenvolvimento do mercado de capitais naquele momento era a limitação da taxa máxima de juros a $12 \%$ ao ano prevista pela Lei da Usura (Decreto-Lei no 22.628/1933). Assim é que, até os anos 1960, a maioria da população brasileira investia em imóveis ao invés de títulos públicos ou privados.

Em meados de 1960 a situação começou a se modificar, especialmente devido à política de incentivos fiscais empreendida pelo Decreto-Lei $\mathrm{n}^{\circ}$ 157/1967, que previa que a compra de valores mobiliários podia ser realizada por meio de descontos em impostos e outros artifícios semelhantes ${ }^{16}$. Parte dessa política foi executada com a criação dos Fundos 157, fundos de investimento em ações que permitiam que os contribuintes do imposto de renda utilizassem parcela do que pagariam ao fisco para a aquisição de quotas desses fundos. A economia brasileira também estava em expansão principalmente devido aos empréstimos adquiridos no exterior. Assim é que no final dos anos 1960 e início dos anos 1970, o mercado de capitais e a economia brasileira estavam em expansão, período ao qual o governo da época atribuiu o nome de "milagre econômico brasileiro".

Tal expansão levou à criação das bases regulatórias do nosso sistema financeiro em sentido amplo. Já em março de 1963, o então presidente João Goulart enviou ao congresso nacional o Projeto de Lei $n^{\circ} 15$, que pretendia:

\footnotetext{
${ }^{16}$ MENDES, Helio Rubens. Art. 5º In: Comentários à Lei do Mercado de Capitais - Lei $n^{o}$ 6.385/76. CODORNIZ, Gabriela; PATELLA, Laura (coord). São Paulo: Quartier Latin, 2015. p. 133.
} 
“a) o estabelecimento de uma administração monetária federal eficiente e flexivel, capaz de formular e executar uma política monetária e creditícia de controle quantitativo global e de caráter seletivo, em moldes nacionais, de forma a conter o processo inflacionário sem afetar o desenvolvimento; $e$

b) promover as modificações que se impõem no regime jurídico das instituições financeiras privadas, de forma a que sua atuação contribua para utilização mais eficiente dos recursos financeiros nacionais, promova distribuição mais equitativa dêsses recursos e facilite o desenvolvimento harmônico das diferentes regiões do Pais" ${ }^{\prime 17}$.

Em 1964, já no governo militar de Castello Branco, o Projeto de Lei $\mathrm{n}^{\circ} 15$ foi aprovado e se transformou na Lei $\mathrm{n}^{\mathrm{o}} 4.595 / 1964$, que instituiu normativamente o sistema financeiro nacional e criou as bases de sua regulação por meio da criação do Conselho Monetário Nacional (CMN), como "órgão regulador de cúpula" ${ }^{18}$, que tem como função formular a política da moeda e de crédito do Brasi ${ }^{19}$, e do Banco Central do Brasil, como "regulador de segundo nível" ${ }^{20}$, responsável pela regulação bancária nacional e executor da política instituída pelo CMN.

No ano seguinte, foi aprovada a primeira lei de mercado de capitais do Brasil, a Lei $n^{\circ} 4.728 / 1965$, para disciplinar o mercado de valores mobiliários e estabelecer medidas para o seu desenvolvimento. $\mathrm{O}$ artigo $1^{\circ}$ da referida lei prevê que "os mercados financeiro e de capitais serão disciplinados pelo Conselho Monetário Nacional e fiscalizados pelo Banco Central da República do Brasil”. Nesse sentido, a supervisão do mercado de capitais brasileiro e de seus participantes passou a ser exercida por uma diretoria especializada do Banco Central do Brasil, a diretoria de mercado de capitais.

Entretanto, o dito milagre da economia brasileira não durou muito. Internamente, a referida política de incentivos fiscais provocou um aumento excessivo na demanda de títulos que não foi acompanhado pela oferta de

\footnotetext{
${ }^{17}$ Mensagem do Presidente da República publicada no Diário do Congresso Nacional, seção I, em 6 de abril de 1963.

${ }^{18}$ VERÇOSA, Haroldo Malheiros Duclerc. Considerações sobre o sistema financeiro. Crises. Regulação e re-regulação. Revista de direito mercantil, industrial, econômico e financeiro. São Paulo: RT, ano XLVII, n. 149-150, jan-dez 2008, p. 17.

${ }^{19}$ Art. $2^{\circ}$ da Lei $n^{\circ} 4.595 / 1964$.

${ }^{20}$ VERÇOSA, Haroldo Malheiros Duclerc. Op. Cit. p. 17.
} 
valores mobiliários, o que gerou uma bolha especulativa no mercado de capitais nacional e a quebra da Bolsa de Valores do Rio de Janeiro em 1971. Externamente, a crise do petróleo de 1973 levou os investidores a serem mais cautelosos no mercado de valores mobiliários, diminuindo seus investimentos.

Nesse momento já se percebia que a estrutura de regulação e fiscalização existente realizada pelo Banco Central não era suficiente para disciplinar e fiscalizar o mercado de capitais. Deu-se início, então, a uma discussão acerca da necessidade da criação de um órgão regulador específico para disciplinar e fiscalizar o mercado de valores mobiliários ${ }^{21}$.

Diante desse cenário, em 1976 foi editada a Lei ${ }^{\circ} 6.385 / 1976^{22}$ que, dentre outros feitos, criou a CVM, entidade autárquica e com capacidade técnica específica para regulamentar e fiscalizar o mercado de capitais, bem como para sancionar os infratores.

Inspirada na Securities and Exchange Comission (SEC), a CVM foi criada com a função de garantir os interesses dos investidores, velar por um sistema de ampla divulgação (full disclosure) assegurando a dispersão homogênea de informações e de estabelecer regras de conduta aos participantes do mercado.

No que se refere à sua autonomia, é imprescindível destacar que a CVM nasceu vinculada tecnicamente ao Ministério da Fazenda, conforme se vê da redação original do artigo $5^{\circ}$ da Lei $n^{\circ} 6.385 / 1976^{23}$.

Entretanto, em 2002, com a edição da Lei $n^{\circ} 10.411 / 2002$, que alterou a Lei $n^{\circ} 6.385 / 1976$, modificou-se a natureza da CVM e retirou-se sua

\footnotetext{
${ }^{21}$ PACHECO, Aline; DE CERQUEIRA, Bruno Saraiva Pedreira; MERQUES, Evy Cynthia; e MILNITZKY, Mariana Ventura. CVM: Limites de sua competência. In: Mercado de Capitais Brasileiro II - Doutrina, Cases \& Materials. PENTEADO, Mauro Rodrigues (coord). São Paulo: Quartier Latin, 2014. p. 33.

${ }^{22}$ Apesar da sua extrema importância, cabe ressaltar que a Lei $n^{\circ} 6.385 / 76$ é o resultado da combinação de pelo menos três anteprojetos de lei e que, segundo Nelson Eizirik, não recebeu atenção mais acurada do Congresso Nacional, quando de sua tramitação. EIZIRIKI, Nelson. $A$ urgente reforma da lei 6.385/76. In: Revista de Direito Mercantil. $\mathrm{n}^{\circ}$ 98. p. 58.

${ }^{23}$ Art. $5^{\circ}$. É instituída a Comissão de Valores Mobiliários, entidade autárquica, vinculada ao Ministério da Fazenda.
} 
vinculação técnica ao Ministério da Fazenda. Veja-se a nova redação do artigo $5^{\circ}$ :

"Art. $5^{o}$ É instituída a Comissão de Valores Mobiliários, entidade autárquica em regime especial, vinculada ao Ministério da Fazenda, com personalidade jurídica e patrimônio próprios, dotada de autoridade administrativa independente, ausência de subordinação hierárquica, mandato fixo e estabilidade de seus dirigentes, $e$ autonomia financeira e orçamentária."

Atualmente, apesar de não ter sido instituída com a nomenclatura ${ }^{24}$, a CVM é uma autarquia considerada uma agência reguladora, "não apenas pela função de controle que execut[a], como também pela similaridade quanto à fisionomia jurídica" 25 .

As agências reguladoras, também chamadas de autarquias de regime especial, surgiram no cenário brasileiro no final dos anos 90 . Se até os anos 80 a percepção político-econômica era a de que o Estado deveria agir como um ente interventor, a partir da influência das políticas econômicas adotadas pelos governos Reagan e Thatcher nos Estados Unidos e Inglaterra nos anos 1980, na década seguinte entrou-se na fase em que o Estado passou a ser visto como um ente regulador ${ }^{26}$.

Os processos de privatizações na América Latina em 1990 foram influenciados por tal alteração na concepção social e política acerca das funções que o Estado deveria exercer na economia e nos setores privados do país ${ }^{27}$. Já em 1988 a nova Constituição da República Federativa do Brasil

\footnotetext{
24 “Anote-se, derradeiramente, que há uma entidade cujas funções são de índole equivalente às das 'agências reguladoras' e à qual também veio a ser atribuído o qualificativo de 'autarquia sob regime especial', mas que não recebeu a designação de agência, pois foi mantido seu nome original: Comissão de Valores Mobiliários - CVM". BANDEIRA DE MELLO, Celso Antônio. Curso de Direito Administrativo. $28^{\text {a }}$ edição. São Paulo: Malheiros, 2011. p. 171.

${ }^{25}$ FILHO, José dos Santos Carvalho. Manual de Direito Administrativo. 31 ed. São Paulo: Atlas, 2017. p. 517.

${ }^{26}$ PACHECO, Aline; DE CERQUEIRA, Bruno Saraiva Pedreira; MERQUES, Evy Cynthia; e MILNITZKY, Mariana Ventura. Op. Cit. p. 36.

27 "Com a política governamental de transferir para o setor privado a execução de serviços públicos, reservando ao Estado a regulamentação, o controle e fiscalização desses serviços, houve a necessidade de criar, na Administração, agências especiais destinadas a esse fim, no interesse dos usuários e da sociedade. Tais agências têm sido denominadas de agências reguladoras e foram instituídas como autarquias sob regime especial, com o propósito de assegurar sua autoridade e autonomia administrativa”. MEIRELLES, Hely Lopes; BURLE FILHO, José Emanuel. Direito Administrativo Brasileiro. $42^{\mathrm{a}}$ edição. São Paulo: Malheiros, 2016. p. 449.
} 
contemplou essa mudança de percepção, prevendo como uma das funções do Estado a atividade regulatória. Veja-se o artigo 174, caput:

"Art. 174. Como agente normativo e regulador da atividade econômica, o Estado exercerá, na forma da lei, as funções de fiscalização, incentivo e planejamento, sendo este determinante para o setor público e indicativo para o setor privado”.

A instituição de órgãos reguladores, porém, passou a constar na Constituição apenas em 1995, com a alteração dos artigos $21, \mathrm{XI}^{28}$ e 177, §2 III $^{29}$, por meio das emendas constitucionais $n^{\circ} 8$ e 9 , respectivamente.

Assim, diante da alteração do pensamento político econômico do final do século passado, a Lei $\mathrm{n}^{\circ} 6.385 / 76$ passou por mudanças estruturais e a CVM converteu-se em uma autarquia de regime especial, adquirindo maior liberdade no exercício de suas atribuições.

Sobre a função principal dessas autarquias, Carvalho Filho explica que:

"A essas autarquias reguladoras foi atribuida a função principal de controlar, em toda a sua extensão, a prestação dos serviços públicos e o exercício de atividades econômicas, bem como a própria atuação das pessoas privadas que passaram a executá-los, inclusive impondo sua adequação aos fins colimados pelo Governo e às estratégias econômicas e administrativas que inspiraram o processo de desestatização" 30 .

Os poderes e atribuições da CVM serão tratados no capítulo a seguir.

\footnotetext{
${ }^{28}$ Art. 21. Compete à União: XI - explorar, diretamente ou mediante autorização, concessão ou permissão, os serviços de telecomunicações, nos termos da lei, que disporá sobre a organização dos serviços, a criação de um órgão regulador e outros aspectos institucionais.

${ }^{29}$ Art. 177. $\S 2^{\circ} \mathrm{A}$ lei a que se refere o $\S 1^{\circ}$ disporá sobre: III - a estrutura e atribuições do órgão regulador do monopólio da União.

${ }^{30}$ FILHO, José dos Santos Carvalho. Op. Cit. p. 517.
} 


\section{II - OS PODERES DA COMISSÃO DE VALORES MOBILIÁRIOS}

Como visto, a CVM tem natureza jurídica de agência reguladora e, como tal, dispõe de poderes legais para regulamentar, fiscalizar e sancionar o mercado de valores mobiliários e seus agentes. Dada a abrangência desses poderes, veremos a seguir as características de cada um.

\section{II.1. Os poderes de fiscalização e regulamentação}

O poder de fiscalizar está previsto no artigo $1^{\mathrm{o} 31}$ e no artigo $8^{\circ}$, inciso III $^{32}$ da Lei $n^{\circ} 6.385 / 1976$, enquanto que o poder de regulamentar é autorizado pelo artigo $8^{\circ}$, inciso $\mathrm{I}^{33}$ da mesma lei.

No que se refere ao poder de fiscalizar, a lei concedeu amplos poderes à autarquia, uma vez que o inciso III do artigo $8^{\circ}$ autoriza a CVM, além de "fiscalizar permanentemente as atividades e os serviços do mercado de valores mobiliários, de que trata o art. 10", fiscalizar também “a veiculação de informações relativas ao mercado, às pessoas que dele participem, e aos valores nele negociados" e também as "companhias abertas".

A respeito da abrangência desse poder, Marcelo Trindade ${ }^{34}$ destaca:

\footnotetext{
"Vê-se, assim, que, enquanto o poder de regulamentar a lei foi conferido à CVM de maneira restrita, limitando-se às matérias 'expressamente previstas' na Lei das S.A e na Lei 6.385/1976, os seus poderes de fiscalização foram atribuídos de maneira
}

\footnotetext{
${ }^{31}$ Art. $1^{\text {o: }}$ Serão disciplinadas e fiscalizadas de acordo com esta Lei as seguintes atividades: I - a emissão e distribuição de valores mobiliários no mercado; II - a negociação e intermediação no mercado de valores mobiliários; III - a negociação e intermediação no mercado de derivativos; IV a organização, o funcionamento e as operações das Bolsas de Valores; V - a organização, o funcionamento e as operações das Bolsas de Mercadorias e Futuros; VI - a administração de carteiras e a custódia de valores mobiliários; VII - a auditoria das companhias abertas; e VIII - os serviços de consultor e analista de valores mobiliários.

32 Art. $8^{\circ}$. Compete à Comissão de Valores Mobiliários: III - fiscalizar permanentemente as atividades e os serviços do mercado de valores mobiliários, de que trata o Art. $1^{\circ}$, bem como a veiculação de informações relativas ao mercado, às pessoas que dele participem, e aos valores nele negociados;

33 Art. $8^{\circ}$ : Compete à Comissão de Valores Mobiliários: I - regulamentar, com observância da política definida pelo Conselho Monetário Nacional, as matérias expressamente previstas nesta Lei e na lei de sociedades por ações.

${ }^{34}$ TRINDADE, Marcelo. Processo Sancionador na CVM: limites e possibilidades. In: A Lei das S.A. em seus 40 anos. VENANCIO FILHO, Alberto; LOBO, Carlos Augusto da Silveira; e ROSMAN, Luiz Alberto Colonna (coord). Rio de Janeiro: Forense, 2017. p. 484.
} 
muito mais ampla, tendo por objeto as atividades e serviços no mercado, as informações nele veiculadas e as companhias abertas e emissores em geral".

A lei autoriza que o poder de fiscalizar seja exercido tanto a priori como a posteriori. Nesse sentido, a atividade preventiva pode ocorrer por meio da atuação consultiva ou de orientação exercida pela CVM aos agentes ou investidores do mercado, conforme prevê o artigo 13 da Lei no 6.385/1976. Caso a autarquia identifique práticas que possam vir a tornar-se ilícitos denominadas pela lei como "situações anormais do mercado" - pode, conforme autorizada pelo $\S^{\circ}$ do artigo $9^{\circ}$ : (i) suspender a negociação de determinado valor mobiliário ou decretar o recesso de bolsa de valores; (ii) suspender ou cancelar os registros de que trata esta Lei; (iii) divulgar informações ou recomendações com o fim de esclarecer ou orientar os participantes do mercado; e (iv) proibir aos participantes do mercado, sob cominação de multa, a prática de atos que especificar, prejudiciais ao seu funcionamento regular.

Com relação ao poder de regulamentar, sua principal faceta é a atuação normativa. Julya Wellisch aponta que o exercício deste poder objetiva, primordialmente, tornar e manter o mercado eficiente e confiável, condições essenciais para seu desenvolvimento. A autora também ressalta que "regulamentar não é só reproduzir analiticamente a lei" ${ }^{35}$, sendo necessário que este poder amplie e complemente a lei ${ }^{36}$. Dessa forma, sendo impossível ao administrador prever, a priori, todas as condutas necessárias para resguardar o interesse público, "notadamente em searas de marcado dinamismo como a econômica" ${ }^{37}$, teve de conceder liberdade à administração para determinar as minúcias dos preceitos legais que lhes dizem respeito.

Sobre a atuação normativa da administração pública, destaca-se que a doutrina discute se não haveria uma quebra do princípio da separação dos poderes, uma vez que o poder de regulamentar poderia acabar por invadir

\footnotetext{
${ }^{35}$ WELLISCH, Julya. Art. $8^{\circ}$. In: CODORNIZ, Gabriela; PATELLA, Laura (coord). Op. Cit. p. 162

${ }^{36}$ Ibid. p. 162.

${ }^{37}$ Ibid. p. 162.
} 
competência legislativa. Para Celso Antonio Bandeira de Mello, contudo, a resposta a essa discussão "não é difícil":

"Dado o princípio constitucional da legalidade, e consequente vedação a que atos inferiores inovem inicialmente na ordem jurídica, resulta claro que as determinações normativas advindas de tais entidades [agências reguladoras] hão de se cifrar a aspectos estritamente técnicos, que estes, sim, podem, na forma da lei, provir de providências subalternas (...)"38.

A esse respeito, Julya Wellisch entende o seguinte:

“(...) o alargamento cada vez maior da atuação normativa do Poder Executivo é consequência inexorável da transformação do próprio Estado de Direito, que abandonou o papel de mero garantidor do status quo que lhe era atribuído pela doutrina liberal de outrora, para assumir funções de agente transformador das atividades social e econômica, por meio, inclusive, da criação de empresas estatais (welfare state) e, posteriormente, deixando de ser agente econômico para passar a exercer funções de órgão regulador e fomentador da economia (neoliberalismo) "39.

Nesse sentido, importante distinguir a mera regulamentação normativa, que apenas dá fiel execução às leis, da regulação normativa, que tem escopo e competência mais alargados, desde que coerentes com seu marco legal.

Cabe registrar que, com relação à CVM, não há que se falar em delegação de atividade legislativa. $\mathrm{O}$ fundamento do poder regulamentar da autarquia está previsto na Constituição, em seu art. 174, que outorgou ao Estado a competência normativa enquanto regulador da atividade econômica.

Como se verá, é pacífico na doutrina que os poderes de regulamentar e fiscalizar atribuídos à CVM integram o poder de polícia da autarquia, que será melhor explicado no subitem a seguir.

\section{II.2. O poder de polícia}

A expressão poder de polícia comporta dois sentidos, um amplo e um estrito. Para Carvalho Filho, em sentido amplo, “poder de polícia significa

\footnotetext{
${ }^{38}$ BANDEIRA DE MELLO, Celso Antônio. Op. Cit. p. 172.

${ }^{39}$ WELLISCH, Julya. Art. $8^{\circ}$. In: CODORNIZ, Gabriela; PATELLA, Laura (coord). Op. Cit. p. 163.
} 
toda e qualquer ação restritiva do Estado em relação aos direitos individuais" $"$. O significado amplo de poder de polícia contempla, inclusive, a função do legislativo, uma vez que são as leis que desenham o perfil do direito, podendo ser mais ou menos restritivas. Hely Lopes Meirelles define poder de polícia como "o mecanismo de frenagem de que dispõe a Administração pública para conter os abusos do direito individual" ${ }^{11}$. Nesse sentido, o Estado "detém a atividade dos particulares que se revelar contrária, nociva ou inconveniente ao bem-estar social, ao desenvolvimento e à segurança nacional" 42 .

Em sentido estrito, poder de polícia é denominado também "polícia administrativa" e significa a prerrogativa que a administração pública tem para restringir e condicionar a propriedade e a liberdade ${ }^{43}$.

Já para Celso Antonio Bandeira de Melo, poder de polícia em sentindo amplo significa "a atividade estatal de condicionar a liberdade e a propriedade ajustando-as aos interesses coletivos" 44 . Em sentindo estrito, poder de polícia estaria relacionado "unicamente com as intervenções, quer gerais e abstratas, como os regulamentos, quer concretas e específicas (tais as autorizações, as licenças, as injunções), do Poder Executivo destinadas a alcançar o mesmo fim de prevenir e obstar ao desenvolvimento de atividades particulares contrastantes com os interesses sociais" $"$.

De toda sorte, apesar dos diversos conceitos doutrinários dos vieses amplo e restrito do poder de polícia, a discussão ultrapassou o âmbito doutrinário e a definição de poder de polícia passou para legislação nacional. O Código Tributário Nacional afirma em seu artigo 48:

"Considera-se poder de polícia a atividade da Administração Pública que, limitando ou disciplinando direito, interesse ou liberdade, regula a prática de ato ou abstenção de fato, em razão do interesse público concernente à segurança, à higiene, à ordem, aos costumes, à disciplina da produção e do mercado, ao exercício

\footnotetext{
${ }^{40}$ FILHO, José dos Santos Carvalho. Op. Cit. p. 78.

${ }^{41}$ MEIRELLES, Hely Lopes; BURLE FILHO, José Emmanuel. Op. Cit. p. 153.

42 Ibid. p. 153.

${ }^{43}$ FILHO, José dos Santos Carvalho. Manual de Direito Administrativo. Op. Cit. p. 78.

${ }^{44}$ BANDEIRA DE MELLO, Celso Antônio. Op. Cit. p. 829.

${ }^{45}$ Ibid. p. 829.
} 
de atividades econômicas dependentes de concessão ou autorização do Poder Público, à tranquilidade pública ou ao respeito à propriedade e aos direitos individuais ou coletivos".

Assim, o objeto do poder de polícia "é todo bem, direito ou atividade individual que possa afetar a coletividade ou pôr em risco a segurança nacional, exigindo, por isso mesmo, regulamentação, controle e contenção pelo Poder Público" 46 .

De forma mais expressa, Celso Antonio Bandeira de Melo lista os valores os quais a polícia administrativa propõe-se a salvaguardar. São eles: a) de segurança pública; b) de ordem pública; c) de tranquilidade pública; d) de higiene e saúde públicas; e) estéticos e artísticos; f) históricos e paisagísticos; g) riquezas naturais; h) de moralidade pública; i) economia popular ${ }^{47}$.

Como se vê, a CVM, exercendo a função de proteger a poupança popular e a credibilidade do mercado, bem como a de estímulo a promoção e expansão do mercado de capitais, é dotada do poder de polícia, prerrogativa que contém os poderes normativo e de fiscalização, inerentes àquele. Os poderes normativo e de fiscalização são instrumentos por meio do qual o poder de polícia se concretiza, restando este último, sem os primeiros, inócuo.

Exercendo sua atividade normativa, a Administração (no caso, a CVM) pode editar tanto atos normativos com conteúdo genérico (decretos, regulamentos, portarias, resoluções, instruções e outros de conteúdo idêntico), quanto atos normativos concretos, como a expedição de licenças e autorizações. E, como ressalta Carvalho Filho, "não adiantaria deter o Estado o poder de impor restrições aos indivíduos se não despusesse dos mecanismos necessários à fiscalização da conduta destes"48.

\footnotetext{
${ }^{46}$ MEIRELLES, Hely Lopes; BURLE FILHO, José Emmanuel. Direito Administrativo Brasileiro. Op. Cit. p. 156.

${ }^{47}$ BANDEIRA DE MELLO, Celso Antônio. Op. Cit. p. 851.

${ }^{48}$ FILHO, José dos Santos Carvalho. Op. Cit. p. 89.
} 
Não há dúvidas, portanto, de que os poderes de regulamentar e fiscalizar estão contidos no poder de polícia da CVM. A discussão que se apresentará a seguir diz respeito a controvérsia sobre a vinculação do poder sancionador da autarquia ao seu poder de polícia.

\section{II.3. O poder sancionador}

Além dos poderes de regulamentar e fiscalizar, o poder sancionador também é atribuído à CVM pela Lei nº 6.385/1976. Os incisos V e VI do artigo $9^{\circ}$ da Lei do Mercado de Capitais conferem à CVM o poder de, respectivamente, "apurar, mediante processo administrativo, atos ilegais e práticas não eqüitativas de administradores, membros do conselho fiscal e acionistas de companhias abertas, dos intermediários e dos demais participantes do mercado" e "aplicar aos autores das infrações indicadas no inciso anterior as penalidades previstas no art. 11, sem prejuízo da responsabilidade civil ou penal".

$\mathrm{O}$ artigo 11 referido no inciso VI do artigo $9^{\circ}$ prevê que a Comissão de Valores Mobiliários poderá impor sanções aos infratores das normas da Lei $n^{\text {o }}$ 6.835/1976 e da Lei n ${ }^{\text {o }} 6.404 / 1976$, de suas resoluções e de outras normas legais cujo cumprimento lhe caiba fiscalizar.

Vê-se, portanto, que a lei atribuiu competência ampla para a CVM "sancionar qualquer pessoa que participe do mercado de valores mobiliários e viole as leis cujo cumprimento lhe cabe fiscalizar" e "poderá fazê-lo não apenas quando se deparar com atos ilegais, mas também com 'práticas não equitativas" $"$.

José Alexandre Tavares Guerreiro destaca que a Lei nº 6.385/1976 “consagrou a summa divisio da responsabilidade, enfatizando que a punição administrativa a cargo da CVM será imposta em caráter autônomo,

\footnotetext{
${ }^{49}$ TRINDADE, Marcelo. In: VENANCIO FILHO, Alberto; LOBO, Carlos Augusto da Silveira; ROSMAN, Luiz Alberto Colonna (coord). Op. Cit. p. 486.
} 
independentemente das consequências civis ou penais dos atos ilegais ou das práticas não equitativas" $"$.

Guerreiro adverte que aplicação do poder sancionador da CVM, por ele chamado de poder disciplinar, somente se legitima quando visa garantir a consecução dos valores e fins do poder sancionador elencados no artigo $4^{\circ}$ da Lei $n^{\circ}$ 6.385/1976. Em última instância, o fim precípuo que justifica o poder sancionador da CVM é a tutela do mercado de valores mobiliários.

\section{II.3.1. Autonomia do poder sancionador com relação ao poder de polícia}

O que se pretende discutir no presente capítulo é a diferença entre as sanções administrativas, que decorrem do poder sancionador atribuído à Administração Pública, e as medidas de polícia, que decorrem do poder de polícia, este entendido como o poder do Estado de regulamentar e fiscalizar atividades exercidas por particulares, e os efeitos práticos da diferença desses conceitos. Tal diferenciação, como aponta Fábio Medina Osório, nem sempre é clara na doutrina, pois “o parentesco das medidas de polícia com as sanções administrativas é forte, podendo produzir confusões" ${ }^{51}$. O autor ressalta, contudo, que se deve buscar distinções adequadas "visto que os regimes jurídicos divergem"52.

Para Medina Osório, a sanção administrativa não está contemplada pelo poder de polícia, sendo o poder sancionador um poder independente daquele:

\footnotetext{
"A sanção administrativa não resulta ligada a um genérico poder de polícia, embora possa, não raro, servir instrumentalmente à atividade administrativa no sentido de uma consecução de determinados objetivos públicos. Não se deve desprezar a intima conexão do poder de polícia com as sanções administrativas, mas tampouco se pode conectá-los de forma a dissipar o conceito e a autonomia da atividade sancionadora, a qual está regida por princípios e regras específicos. $E$ ́́ verdade, não obstante, que o poder sancionador derivou do poder de polícia, dele
}

\footnotetext{
${ }^{50}$ GUERREIRO, José Alexandre Tavares. Sobre o Poder Disciplinar da CVM. In: Revista de Direito Mercantil, Industrial, Econômico e Financeiro. vol 43. São Paulo: Revista dos Tribunais, 1981. p. 65.

${ }^{51}$ OSÓRIO, Fábio Medina. Direito Administrativo Sancionador. $5^{\text {a }}$ edição. São Paulo: Revista dos Tribunais, 2015. p. 110.

${ }^{52}$ Idem, p. 110
} 
se tornando autônomo, para adquirir contornos jurídicos mais próximos ao Direito Penal. $^{53 ",}$

Marcelo Trindade, nesse mesmo sentido, também considera que o poder sancionador conferido à CVM não se confunde com o poder de polícia e os poderes de repressão que decorrem deste ${ }^{54}$. O ex diretor presidente da CVM entende que "o poder de polícia abrange apenas a regulamentação, a fiscalização e a repressão imediata às violações verificadas pela autoridade administrativa" 55 . O poder sancionador, que ele classifica como "o poder de impor ao infrator uma pena segundo a gradação legal, por meio de prévia apuração, posterior formulação de acusação, e após devido processo" seria, portanto, um poder autônomo em relação ao poder de polícia, embora com ele se relacione ${ }^{56}$.

Nessa linha, veja-se o pensamento de Alexandre Pinheiro dos Santos, Fábio Medina Osório e Julya Sotto Mayor Wellish:

"O regime jurídico sancionador é um novo regime, que rompe os padrões tradicionalmente adotados no trato do seu objeto e busca, em última análise, uma visão transdisciplinar. Com efeito, tal regime jurídico pressupõe uma singular aproximação entre o Direito Penal e o Direito Administrativo e recomenda, em especial, uma abordagem sistemática do Direito Penal e Direito Administrativo Sancionador, no âmbito do denominado devido processo penal punitivo "57.

\footnotetext{
${ }^{53}$ Ibid. p. 111.

${ }^{54}$ TRINDADE, Marcelo. In: VENANCIO FILHO, Alberto; LOBO, Carlos Augusto da Silveira; ROSMAN, Luiz Alberto Colonna (coord). Op. Cit. p. 490

${ }^{55}$ Vale dizer, no que se refere à expressão "repressão imediata" utilizada por Trindade, que Fábio Medina afirma que as medidas de polícia podem estar ligadas ao perigo de cometimento de um fato ilícito. Assim, ao contrário do que ocorre com as sanções administrativas, as medidas de polícia podem ter um caráter preventivo "perseguindo o bem comum, a consecução da boa ordem no uso dos bens e serviços públicos, visando o exato cumprimento da lei e das disposições normativas pertinentes”. OSÓRIO, Fábio Medina. Op. Cit. pp. 108-109.

56 Cite-se os exemplos utilizados por Trindade para diferenciar o poder de repressão consubstanciado no poder de polícia do poder sancionador: o poder previsto no inciso IV do art. $9^{\circ}$ de "determinar às companhias abertas que republiquem, com correções ou aditamentos, demonstrações financeiras, relatórios ou informações divulgadas" refere-se ao poder de repressão; já "prevenir ou corrigir situações anormais de mercado" por meio dos atos previstos no $\S 1^{\circ}$ do art. $9^{\circ}$ corresponde ao poder sancionador. TRINDADE, Marcelo. In: VENANCIO FILHO, Alberto; LOBO, Carlos Augusto da Silveira; ROSMAN, Luiz Alberto Colonna (coord). Op. Cit. p. 489.

${ }^{57}$ DOS SANTOS, Alexandre Pinheiro; OSÓRIO, Fábio Medina; WELLISCH, Julya Sotto Mayor. Mercado de Capitais: Regime Sancionador. São Paulo: Saraiva, 2012. p. 25
} 
Assim, parte da doutrina entende que o poder sancionador da CVM não se confunde com o poder de repressão que a autarquia possui decorrente do poder de polícia (medidas de polícia). O poder de repressão seria uma consequência do poder de regulamentar e de fiscalizar o mercado. Isto é, se os agentes regulados praticam uma conduta indevida (assim classificada devido ao poder de regulamentação), a autarquia, tendo exercido seu poder de fiscalização, teria o poder de "reagir" e repreendê-los. As medidas de poder de polícia são, portanto, uma resposta da CVM à infração (ou a iminente infração, no caso da medida preventiva) de uma de suas normas. Mas, apesar de "estar ligadas ao cometimento ou ao perigo de cometimento de um fato ilícito" as medidas de polícia não possuem um caráter punitivo ${ }^{58}$. Assim, conforme conclui Medina Osório, não configura sanção administrativa quando o Estado veda ao indivíduo um exercício de um direito para o qual não estava habilitado ${ }^{59}$.

Diferente situação ocorre quando a CVM investiga ilícitos no mercado por meio de um processo administrativo. Nesses casos, a Administração Pública tem o dever de observar os princípios constitucionais aplicáveis ao direito punitivo (os quais serão abordados no capítulo IV), uma vez que tanto o processo administrativo quanto as sanções administrativas têm o condão de interferir e restringir importantes direitos individuais, conforme afirmam Julya Sotto Mayor Wellisch, Alexandre Pinheiro dos Santos e Fábio Medina Osório:

\footnotetext{
"De qualquer sorte, é sempre importante lembrar que a proteção de valores substantivos está na raiz de todo o sistema sancionador, seja na esfera penal, seja na esfera administrativa. Como reflexo dessa premissa, está o consectário lógico de que as medidas que consubstanciam respostas punitivas aos atos ilícitos traduzem restrições a direitos individuais valiosos ${ }^{" 60}$.
}

\footnotetext{
58 OSÓRIO, Fábio Medina. Op. Cit. p. 109.

59 Ibid. p. 109.

60 DOS SANTOS, Alexandre Pinheiro; OSÓRIO, Fábio Medina; WELLISCH, Julya Sotto Mayor. Op. Cit. p. 27.
} 
Assim, a presente discussão é de suma importância prática na medida em que as sanções administrativas, diferentemente das medidas de polícia, podem atingir direitos fundamentais dos indivíduos. Mais uma vez, Fábio Medina Osório deixa clara essa diferença ${ }^{61}$ :

"Sem embargo, não prospera, em sua globalidade, a teoria de que o poder sancionador estaria integrado no poder de polícia, diante das peculiaridades do direito administrativo sancionador, suas garantias, sua generalidade, tipicidade, legalidade, incompatibilidade com a flexível e extremamente elástica natureza que deveria ostentar para ser considerado integrante do poder de polícia "62.

Vê-se que o poder sancionador da CVM encontra limites constitucionais rígidos de proteção aos direitos fundamentais, como o direito ao devido processo legal, ampla defesa e presunção de inocência.

\footnotetext{
${ }^{61}$ No mesmo sentido: "O terreno punitivo - e os seus efeitos sobre os direitos fundamentais - não se resume ao Direito Penal. Como antes referido, abrange também o exercício de funções repressivas pela Administração Pública. E a denominada Teoria da Sanção do século XIX, na Europa, ressaltou a aproximação do Direito Penal e do Direito Administrativo. Essa teoria significou, para o Direito Administrativo, uma forma de recortar o poder de polícia e enquadrar determinadas medidas em um regime jurídico menos verticalizado e mais horizontalizado, bem como mais comprometido com os direitos humanos, em detrimento de interesses gerais abstratos". Ibid. p. 31.

${ }^{62}$ OSÓRIO, Fábio Medina. Op. Cit. p. 111.
} 


\section{III - O PROCESSO ADMINITRATIVO SANCIONADOR NA CVM}

Conforme supramencionado, os valores atribuídos pelo legislador ao mercado de capitais encontram-se discriminados no art. $4^{\circ}$ da Lei $n^{\circ}$ 6.385/1976. É nessa enumeração programática e valorativa, conforme afirma Guerreiro $^{63}$, que se encontram os fins que justificam o poder sancionador (por ele chamado de poder disciplinar) da CVM.

No que se refere ao procedimento para atingir tal fim, com a recente edição das Instruções CVM nº 607/2019, no 608/2019 e nº 609/2019 neste ano, criou-se um novo marco que regula o processo administrativo sancionador da CVM. Essas recentes instruções dispõem sobre o rito dos procedimentos relativos aos processos sancionadores (PAS), bem como atualizam o regime e os valores relacionados às multas cominatórias aplicáveis pela autarquia. A criação desse novo marco regulatório teve direta relação com a edição da Lei $n^{\circ} 13.506 / 2017$, que reformou artigos da Lei ${ }^{\circ}$ 6.404/1976 e da Lei nº 6.385/1976 e sobre a qual se falará adiante.

Para melhor entendermos o processo administrativo sancionador na CVM atualmente e os limites que lhe podem ser impostos, será analisada a seguir sua evolução histórica e as normas atualmente vigentes de forma a identificar seus destinatários, a forma como o processo ocorre e as penalidades aplicáveis àqueles que praticam os ilícitos.

\section{III.1. Breve histórico da regulação da atividade sancionadora da CVM}

Como já visto, o poder da CVM de apurar atos ilegais e práticas não equiitativas de participantes do mercado de valores mobiliários por meio de processo administrativo decorre da Lei $\mathrm{n}^{\mathrm{o}} 6.385 / 1976^{64}$. Tal lei sofreu

\footnotetext{
${ }^{63}$ GUERREIRO, José Alexandre Tavares. Op. Cit. p. 66.

${ }^{64}$ Art $9^{\circ}$ A Comissão de Valores Mobiliários, observado o disposto no $§ 2^{\circ}$ do art. 15 , poderá: V apurar, mediante processo administrativo, atos ilegais e práticas não eqüitativas de administradores, membros do conselho fiscal e acionistas de companhias abertas, dos intermediários e dos demais participantes do mercado.
} 
diversas alterações desde o seu nascimento, em 1976, e foi por algumas vezes reformada de forma mais intensa.

A primeira reforma mais profunda da lei ocorreu em 1997, quando foi alterada de forma a refletir o processo das privatizações ocorridas no Brasil no final dos anos 1990, época em que ainda havia muitas empresas estatais que oneravam a administração pública. Com o intuito de organizar as finanças do Estado e reduzir o déficit público, em 1997 foi editada a Lei no 9.491/97, que instituiu o Plano Nacional de Desestatização - PND, transferindo à iniciativa privada os serviços que o Estado prestava de forma ineficiente por meio das estatais ${ }^{65}$. Assim é que em 1997 editou-se a Lei ${ }^{\circ}$ 9.457/1997 por meio da qual alguns dispositivos da Lei das Sociedades Anônimas ${ }^{66}$ e da Lei $\mathrm{n}^{\mathrm{o}} 6.385 / 1976^{67}$ foram alterados. As alterações realizadas na Lei $n^{\circ}$ 6.385/76 intensificaram e aprimoraram os poderes sancionadores da CVM. O rol previsto no art. 11 da lei, que prevê as penalidades a serem aplicadas pela CVM, por exemplo, foi aumentado, bem como introduziu-se no $\$ 5^{\circ}$ do mesmo artigo a possibilidade de extinção dos processos administrativos por meio da celebração de termo de compromisso. Nas palavras de Marcelo Trindade, as mudanças na lei foram uma "espécie de contrapartida às alterações destinadas a estruturar o processo de privatização"68.

Posteriormente, em 2001, a Lei nº 6.385/1976 passou por outra reforma intensa com a edição da Lei $n^{\circ} 10.303 / 2001$. Dessa vez, segundo Trindade, as mudanças "buscavam promover o desenvolvimento do mercado de valores mobiliários, especialmente sob a ótica da governança corporativa" ${ }^{69}$. Nessa oportunidade, ampliou-se o conceito de valor mobiliário tendo sido incluídos

\footnotetext{
${ }^{65}$ FILHO, José dos Santos Carvalho. Op. Cit. p. 516.

${ }^{66}$ Os arts. 16, 17, 24, 39, 40, 42, 43, 45, 49, 50, 63, 64, 72, 78, 79, 100, 101, 104, 117, 123, 126, $136,137,152,162,163,170,176,206,223,229,230,250,252,255,264,270,283,289$ e 294 da Lei $\mathrm{n}^{\circ} 6.404 / 1976$ foram alterados.

${ }^{67}$ Os arts. $9^{\circ}, 11,15,17,21$ e 22 da Lei ${ }^{\circ}$ 6.385/1976 foram alterados e o art. 33 foi incluído.

${ }^{68}$ TRINDADE, Marcelo. In: VENANCIO FILHO, Alberto; LOBO, Carlos Augusto da Silveira; ROSMAN, Luiz Alberto Colonna (coord). Op. Cit. p. 482.

${ }^{69}$ Ibid. p. 482.
} 
seis incisos na enumeração do art. $2^{\circ}$ da lei ${ }^{70}$, além da redação de diversos outros artigos terem sido modificadas para aumentar a competência da CVM e de ter sido incluído no diploma o capítulo VII, que dispõe sobre os crimes contra o mercado de capitais.

Mais recentemente, em 2017, a Lei n 6.385/1976 sofreu novamente profundas mudanças. As alterações vieram da edição da Lei n ${ }^{\circ}$ 13.506/2017, que reformou artigos importantes para a atividade sancionadora da CVM. Um dos dispositivos alterados foi o $\S 4^{\circ}$ do art. $9^{\circ}$, que passou a prever explicitamente que a CVM, "na apuração de infrações da legislação do mercado de valores mobiliários", "priorizará as infrações de natureza grave, cuja apenação proporcione maior efeito educativo e preventivo para os participantes do mercado, e poderá deixar de instaurar o processo administrativo sancionador, consideradas a pouca relevância da conduta, a baixa expressividade da lesão ao bem jurídico tutelado e a utilização de outros instrumentos e medidas de supervisão que julgar mais efetivos"71. Apesar de estabelecer critérios subjetivos para a não instalação de PAS, a nova redação do $\$ 4^{\circ}$ aprimora a atuação sancionadora da autarquia, que deve, agora por previsão legal, focar seus esforços e recursos em infrações que causem efeitos relevantes no equilíbrio do mercado ou no bem jurídico tutelado.

Outro ponto importante trazido por essa reforma foi a elucidação com relação a aplicação cumulativa das penalidades previstas no art. 11 da lei, o que era muito discutido até então. A partir da edição da Lei n ${ }^{\circ}$ 13.506/2017,

\footnotetext{
${ }^{70}$ São eles: "IV - as cédulas de debêntures; V - as cotas de fundos de investimento em valores mobiliários ou de clubes de investimento em quaisquer ativos; VI - as notas comerciais; VII - os contratos futuros, de opções e outros derivativos, cujos ativos subjacentes sejam valores mobiliários; VIII - outros contratos derivativos, independentemente dos ativos subjacentes; e IX - quando ofertados publicamente, quaisquer outros títulos ou contratos de investimento coletivo, que gerem direito de participação, de parceria ou de remuneração, inclusive resultante de prestação de serviços, cujos rendimentos advêm do esforço do empreendedor ou de terceiros".

$71 \S 4^{\circ} \mathrm{Na}$ apuração de infrações da legislação do mercado de valores mobiliários, a Comissão priorizará as infrações de natureza grave, cuja apenação proporcione maior efeito educativo e preventivo para os participantes do mercado, e poderá deixar de instaurar o processo administrativo sancionador, consideradas a pouca relevância da conduta, a baixa expressividade da lesão ao bem jurídico tutelado e a utilização de outros instrumentos e medidas de supervisão que julgar mais efetivos.
} 
o art. 11 da Lei $n^{\circ}$ 6.385/1976 passou a explicitar que as penas ali previstas podem ser aplicadas pela autarquia isolada ou cumulativamente ${ }^{72}$.

Ainda no que se refere ao art. 11, a Lei n 13.506/2017 também alterou os valores das multas que podem ser aplicadas pela CVM, estabelecidos no $\S 1^{\text {o } 73}$ do referido artigo. As mudanças consistem no aumento do valor máximo da multa quando não calculada com base na vantagem obtida ou no valor da operação irregular, que pulou de $\mathrm{R} \$ 500.000,00$ para $\mathrm{R} \$ 50.000 .000,00^{74}$ e no aumento do percentual da multa que pode ser aplicada quando da ocorrência de operações irregulares, que antes era de 50\% do valor da operação e passou para até o dobro do valor da emissão ou operação irregular. Foi incluída também previsão de que a CVM poderá multar em até o dobro do valor do prejuízo causado aos investidores em decorrência de ilícitos. Vale dizer que, com relação ao valor da multa baseada no montante da vantagem econômica obtida, este se manteve igual, no patamar de, no máximo, o triplo. Além disso, ficou previsto no $\S 2^{\circ}$ do art. 11 que nas hipóteses de reincidência poderá ser aplicada multa de até o triplo dos valores fixados no $\S 1^{\text {o75 }}$.

Sobre a Lei $\mathrm{n}^{\mathrm{o}}$ 13.506/2017, ressalta-se também que este diploma introduziu mudança importante com relação aos efeitos de recursos interpostos contra decisão da CVM que aplica as penalidades previstas nos

\footnotetext{
72 Art. 11. A Comissão de Valores Mobiliários poderá impor aos infratores das normas desta Lei, da Lei $\mathrm{n}^{\circ}$ 6.404, de 15 de dezembro de 1976 (Lei de Sociedades por Ações), de suas resoluções e de outras normas legais cujo cumprimento lhe caiba fiscalizar as seguintes penalidades, isoladas ou cumulativamente

${ }^{73} \S 1^{\circ}$. Com o fim de prevenir ou corrigir situações anormais do mercado, a Comissão poderá: I - suspender a negociação de determinado valor mobiliário ou decretar o recesso de bolsa de valores; Il - suspender ou cancelar os registros de que trata esta Lei; III - divulgar informações ou recomendações com o fim de esclarecer ou orientar os participantes do mercado; IV - proibir aos participantes do mercado, sob cominação de multa, a prática de atos que especificar, prejudiciais ao seu funcionamento regular.

${ }^{74}$ A MP 784/2017, que precedeu a edição da Lei no $13.506 / 2017$, previa o limite máximo da multa aplicável pela CVM no valor de $\mathrm{R} \$ 500.000 .000,00$. A MP não foi convertida em lei e teve sua vigência encerrada em 19.10.2017. Apesar de não ter sido convertida em lei, a MP ensejou a criação do Projeto Lei $n^{\circ}$ 8843/2017, que foi transformado na Lei Ordinária 13.506/2017.

75 Ainda sobre a aplicação de multas, a Lei $n^{\circ}$ 13.506/2017 estabeleceu também um relevante aumento no valor máximo de multa que a CVM poderá aplicar no caso de inexecução de ordem emitida pela autarquia, independentemente da existência de processo administrativo sancionador, para o maior de: (i) um milésimo do faturamento total individual ou consolidado do grupo econômico no exercício anterior à aplicação da multa; ou (ii) R \$ 100.000,00.
} 
incisos IV, V, VI, VII e VIII do art. $11^{76}$ da Lei $n^{\circ}$ 6.385/1976. De acordo com a Lei no $13.506 / 2017$, tais recursos passaram a ter efeito devolutivo no lugar de efeito suspensivo. Ainda que a lei estabeleça que o recorrente pode requerer o efeito suspensivo à autoridade prolatora da decisão, fato é que essa mudança fortalece o poder sancionador da autarquia, tanto porque em determinados casos os efeitos da decisão são de difícil reversão, quanto porque as penalidades mencionadas são as mais gravosas previstas na lei.

Especificamente sobre o processo administrativo sancionador da CVM (PAS), sua principal feição alterada ao longo do tempo diz respeito à aquisição de autonomia pelos superintendentes da autarquia para interpor peças acusatórias sem a aprovação do colegiado da CVM, fato que só ocorreu em 2002, com a edição da Deliberação CVM nº 457/200277.

Em um primeiro momento, até o início da década de 90, conforme disposto na Deliberação CVM n ${ }^{\circ}$ 12/1981 e na Deliberação CVM nº 16/1984, vigentes à época, e na Resolução nº 454/1977 do CMN, a instauração de inquéritos administrativos ${ }^{78}$ pela CVM dependia de aprovação do colegiado da autarquia, que também era responsável por designar o superintendente encarregado do inquérito. Realizado o inquérito, o superintendente apresentava um relatório ao colegiado, que poderia (a) determinar a realização de diligências; (b) arquivar o caso; ou (c) concluir pela responsabilização, caso em que o acusado era intimado para apresentação de

\footnotetext{
${ }^{76} \mathrm{IV}$ - inabilitação temporária, até o máximo de 20 (vinte) anos, para o exercício de cargo de administrador ou de conselheiro fiscal de companhia aberta, de entidade do sistema de distribuição ou de outras entidades que dependam de autorização ou registro na Comissão de Valores Mobiliários; V - suspensão da autorização ou registro para o exercício das atividades de que trata esta Lei; VI - inabilitação temporária, até o máximo de 20 (vinte) anos, para o exercício das atividades de que trata esta Lei; VII - proibição temporária, até o máximo de vinte anos, de praticar determinadas atividades ou operações, para os integrantes do sistema de distribuição ou de outras entidades que dependam de autorização ou registro na Comissão de Valores Mobiliários; VIII proibição temporária, até o máximo de dez anos, de atuar, direta ou indiretamente, em uma ou mais modalidades de operação no mercado de valores mobiliários.

${ }^{77}$ Art. $1^{\circ}$. Fica delegada à Superintendência Geral a competência a que se refere o art. $2^{\circ}$ da Resolução $\mathrm{n}^{\circ}$ 454, de 16 de novembro de 1977, com redação dada pela Resolução $\mathrm{n}^{\circ} 2.785$, de 18 de outubro de 2000, ambas do Conselho Monetário Nacional, para determinar a instauração de inquérito administrativo, designar os membros de Comissões de Inquérito e prorrogar o prazo de investigação.

${ }^{78} \mathrm{~A}$ redação anterior do inciso $\mathrm{V}$ do art. $9^{\circ}$ da Lei $\mathrm{n}^{\circ} 6.385 / 1976$ previa que a CVM poderia apurar atos ilegais e práticas não eqüitativas por meio de inquéritos administrativos, e não de processo sancionador.
} 
defesa ${ }^{79 / 80}$. Após o contraditório, o colegiado realizava o julgamento do feito, absolvendo ou aplicando penalidades ao acusado ${ }^{81}$.

Percebe-se que, nesse período, o colegiado da CVM exercia uma espécie de "controle prévio" sobre as peças acusatórias, pois, de certa forma, fazia parte do órgão acusador na medida em que tinha o poder de determinar a realização de diligências que amparavam a acusação, bem como a inclusão, ou não, de outros acusados nos processos.

Em 1994, foram criadas por meio da Deliberação CVM n ${ }^{\circ}$ 175/1994 que revogou as Deliberações CVM n 12 e 16 -, as Comissões de Inquérito, fato que não alterou a dinâmica da instauração de processos com relação ao colegiado da autarquia. Ou seja, ainda era necessária a aprovação do colegiado para instauração do inquérito administrativo, bem como do posterior relatório da Comissão de Inquérito ${ }^{82}$.

Assim é que, naquela época, excluindo-se as hipóteses nas quais era cabível o rito sumário ${ }^{83}$, os ilícitos contra o mercado de capitais somente poderiam ser apurados mediante a instauração de inquérito administrativo, o

\footnotetext{
${ }^{79}$ Deliberação CVM no 16/1984. I - A instauração de inquérito administrativo para apurar atos ilegais e práticas não eqüitativas de administradores e acionistas de companhias abertas, dos intermediários e dos demais participantes do mercado (Lei $\mathrm{n}^{\circ}$ 6.385, de 07/12/76, art. $9^{\circ}$, V), dependerá de aprovação do Colegiado, em expediente que lhe seja submetido por um de seus membros, ou pelo titular de qualquer de suas Superintendências, do qual deverão constar a individualização do indiciado e a descrição dos fatos que fundamentam o pedido. II - Aprovada a instauração do inquérito, o Colegiado no mesmo ato designará o Superintendente encarregado de sua instrução. III - No curso da instrução, o Superintendente dela encarregado poderá, a qualquer tempo, verificando a correlação de procedimentos e fatos, solicitar a indicação de outras pessoas no mesmo inquérito, ou em novo inquérito a ser instaurado, o que caberá ao Colegiado decidir. A solicitação deverá observar os requisitos exigidos para o pedido de instauração de inquérito. IV Terminada a instrução do inquérito administrativo, o Superintendente dela encarregado deverá elaborar relatório a ser submetido à apreciação do Colegiado.

${ }^{80}$ Deliberação CVM n ${ }^{\text {1 }}$ 12/1981. I - Fica atribuída aos membros do Colegiado da CVM designados relatores dos inquéritos administrativos da CVM competência para apreciar o pedido de provas formulado na defesa do acusado, bem como para presidir as diligências necessárias à sua produção. ${ }^{81}$ WELLISCH, Julya Sotto Mayor. DOS SANTOS, Alexandre Pinheiro. A Evolução do Processo Administrativo Sancionador no Âmbito da Comissão de Valores Mobiliários. Revista de Direito Bancário e do Mercado de Capitais, vol. 48/2010. pp. 53 - 80.

${ }^{82}$ Deliberação CVM n ${ }^{\circ}$ 175/1994. II - Aprovada a instauração do inquérito administrativo, o Colegiado designará a Comissão de Inquérito, que será nomeada por Portaria assinada pelo Presidente da CVM. IV - Concluída a instrução, a Comissão dela encarregada deverá elaborar relatório a ser submetido à apreciação do Colegiado. VI - O Colegiado, recebendo o relatório, designará entre os seus membros um relator para apreciá-lo.

${ }^{83} \mathrm{O}$ rito sumário podia ser adotado, conforme previsto no Regulamento anexo à Resolução CMN n ${ }^{\circ}$ 1657/1989 e na Instrução CVM nº 135/1990 e, posteriormente na Instrução CVM nº 251/1996, nas hipóteses de infração de natureza objetiva previstas nos referidos diplomas.
} 
que, observam Julya Wellisch e Alexandre Pinheiro dos Santos “demandava não apenas tempo, mas também recursos materiais e humanos muitas vezes desproporcionais à lesão causada pela infração que se pretendia punir" ${ }^{\text {"84 }}$.

Em 2000, a Resolução do $\mathrm{CMN}^{\circ}$ 2.785/2000 passou a dispensar a constituição de Comissão de Inquérito quando os elementos de autoria e materialidade da infração fossem suficientes para o oferecimento de termo de acusação por um superintendente da autarquia, o qual deveria submetê-lo, de forma sumária, à aprovação do Colegiado da Autarquia. Os autores supracitados destacam que "apesar do avanço alcançado com a possibilidade de oferecimento de Termo de Acusação pelo próprio Superintendente da área afeta ao mérito do processo, o fato é que, ainda assim, o procedimento sancionador no âmbito da CVM ainda se mostrava lento" 85 .

Tal cenário alterou-se em 2002, conforme já se destacou acima, quando o colegiado da CVM deixou de analisar e aprovar as peças acusatórias que dão início a um processo administrativo sancionador, ficado a cargo dos superintendentes da autarquia e das comissões de inquérito a função acusatória. No âmbito dos processos sancionadores, restou ao colegiado da autarquia apenas a função julgadora.

\section{III.2. O atual processo administrativo sancionador da CVM e seu novo marco regulatório}

No final de junho deste ano, a CVM aprovou a edição da Instrução CVM n ${ }^{\circ} 607$ e mais três diplomas a ela relacionadas ${ }^{86}$ que compõem, atualmente, a espinha dorsal do processo administrativo sancionador da autarquia. Tais diplomas revogaram diversas outras normas esparsas que se aplicavam ao $\mathrm{PAS}^{87}$ e consolidaram o tema a fim de trazer mais segurança jurídica para os regulados.

\footnotetext{
${ }^{84}$ WELLISCH, Julya Sotto Mayor. DOS SANTOS, Alexandre Pinheiro. Op. Cit. p. 53.

${ }^{85}$ Ibid. p. 53.

${ }^{86}$ São eles: Instrução CVM nº 608, Instrução CVM nº 609 e a Deliberação CVM no 819.

${ }^{87}$ Foram revogados os seguintes normativos: (i) Deliberação CVM no 390/01, sobre celebração de Termo de Compromisso; (ii) Deliberação CVM n ${ }^{\circ}$ 538/08, sobre processos administrativos sancionadores; (iii) Deliberação $\mathrm{CVM} \mathrm{n}^{\circ} 542 / 08$, sobre a adoção de procedimentos preventivos e
} 
O fim que justifica o poder sancionador da CVM é a tutela do mercado de valores mobiliários. Nesse sentido, conforme já se afirmou, no mercado de capitais nem sempre é possível identificar os agentes maliciosos a tempo de evitar danos que desequilibrem o mercado e, por isso, faz-se necessária a existência de um ente regulador.

No que se refere ao PAS, como visto acima, sua instalação fica a cargo dos superintendentes da CVM desde 2002. Nesse âmbito, importa destacar que a ICVM n 607 replicou em parte a redação do $\$ 4^{\circ}$ do art. $9^{\circ}$ da Lei $n^{\circ}$ 6.385/1976, alterada pela Lei $n^{0} 13.506 / 2017$, que, como já se salientou, prevê que a autarquia "priorizará a apuração das infrações de natureza grave, cuja apenação proporcione maior efeito educativo e preventivo para os participantes do mercado e que poderá deixar de instaurar o processo administrativo sancionador, consideradas a pouca relevância da conduta, a baixa expressividade da lesão ao bem jurídico tutelado e a utilização de outros instrumentos e medidas de supervisão que julgar mais efetivos". Nesse sentido, a ICVM no 607 estabelece os mesmos critérios para que os superintendentes deixem de instalar o PAS.

$\mathrm{O} \S 1^{\circ}$ do referido artigo prevê ainda que "na avaliação da relevância da conduta ou da expressividade da ameaça ou lesão ao bem jurídico”, poderão ser utilizados determinados parâmetros, mais uma vez subjetivos, mas que não deixam de balizar a atuação da autarquia. São eles (dentre outros): (i) o grau de reprovabilidade ou da repercussão da conduta; (ii) a expressividade de valores relacionados à conduta; (iii) a expressividade de prejuízos causados a investidores e demais participantes do mercado; (iv) o impacto da conduta na credibilidade do mercado de capitais; (v) os antecedentes das pessoas envolvidas; (vi) a boa-fé das pessoas envolvidas; (vii) a regularização da suposta infração pelo administrado; e (viii) o ressarcimento dos investidores lesados.

orientadores no âmbito da atividade fiscalizadora da CVM; (iv) Deliberação CVM n ${ }^{\circ}$ 552/08, sobre

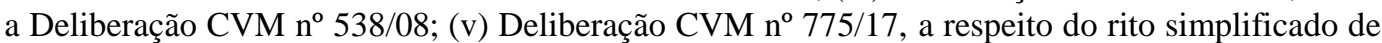
processo administrativo sancionador no âmbito da CVM; e (vi) Instrução CVM n 491/11, sobre hipóteses de infração grave, nos termos do $\S 3^{\circ}$ do art. 11 da Lei ${ }^{\circ}$ 6.385/76. 
A ICVM n 607 prevê como outros instrumentos ou medidas de supervisão alternativos à instauração do PAS a expedição de ofício de alerta e a atuação prévia e coordenada de instituição autorreguladora. Tais medidas são certamente mais brandas do que a instalação de um processo administrativo sancionador e serão abordadas de forma mais detalhada no Capítulo IV deste trabalho.

Após a análise dos requisitos acima expostos, caso a superintendência decida lavrar o termo de acusação, observados os requisitos previstos no art. $6^{0}$ da instrução ${ }^{88}$, deve, previamente à formulação da acusação, obter diretamente do investigado esclarecimentos sobre os fatos que podem ser a ele imputados ${ }^{89}$. Antes da citação dos acusados, a Procuradoria Federal Especializada deve emitir parecer sobre o termo de acusação, no qual analisará se houve manifestação prévia do acusado, se os requisitos objetivos do art. $6^{\circ}$ foram observados e examinará a adequação do rito adotado para o processo administrativo sancionador ${ }^{90 / 91}$.

Se por um lado a instrução estabelece limites formais impostos ao poder sancionador da CVM, por outro a ICVM no 607 deu maior atenção ao princípio da convalidação dos atos administrativos, o que significa que caso haja inadequação do termo de acusação com relação a algum dos requisitos acima, o ato não será nulo e a superintendência poderá tomar as providências cabíveis para adequar o rito processual ou realizar eventuais ajustes no termo de acusação, ou ainda, poderá arquivar o processo..$^{92}$

\footnotetext{
${ }^{88}$ Art. $6^{\circ}$. Nas hipóteses em que a superintendência considerar que dispõe de elementos conclusivos quanto à autoria e à materialidade da irregularidade constatada, deverá ser lavrado termo de acusação do qual constará: I - nome e qualificação dos acusados; II - narrativa dos fatos investigados que demonstre a materialidade das infrações apuradas; III - análise de autoria das infrações apuradas, contendo a individualização da conduta dos acusados, fazendo-se remissão expressa às provas que demonstrem sua participação nas infrações apuradas; IV - descrição dos esclarecimentos prestados nos termos do art. $5^{\circ} ; \mathrm{V}$ - os dispositivos legais ou regulamentares infringidos; VI - rito a ser observado no processo administrativo sancionador; e VII - proposta de comunicação a que se refere $\mathrm{o}$ art. 13, se for o caso.

${ }^{89}$ Art. $5^{\circ}$ da Instrução CVM n ${ }^{\circ} 607$.

${ }^{90}$ Art. $7^{\circ}$ da Instrução CVM n ${ }^{\circ} 607$.

${ }^{91}$ De acordo com o art. $7^{\circ}, \S 3^{\circ}$ da Instrução ${ }^{\circ}$ 607, o parecer da PFE não será obrigatório nos processos administrativos sancionadores submetidos ao rito simplificado de que trata o art. $73 \mathrm{da}$ Instrução.

${ }^{92}$ Art. $7^{\circ}, \S 1^{\circ}$ da Instrução CVM n ${ }^{\circ} 607$.
} 
Atendidos os requisitos relacionados à formulação do termo de acusação, a citação do acusado deverá ocorrer preferencialmente por meio eletrônico ${ }^{93}$. A citação por meio eletrônico foi uma das principais alterações trazidas pela ICVM n ${ }^{\circ}$ 607, que também considera como dever do acusado, ou do procurador por ele constituído, o de se cadastrar no SEI, registro eletrônico da CVM, para fins de acesso aos autos e posterior acompanhamento do andamento do processo ${ }^{94}$.

Os acusados em um PAS têm 30 dias para apresentar defesa por escrito e, se desejarem realizar termo de compromisso, devem manifestar sua vontade dentro desse mesmo prazo que, aliás, é contado em dias úteis (mudança trazida pela ICVM no 607 para que haja alinhamento com a contagem processual do Código de Processo Civil ${ }^{95}$. Vale destacar também que com o novo marco legal, só é admitida uma prorrogação do prazo de apresentação de defesa, pelo mesmo prazo e diante de pedido devidamente fundamentado 96 .

Ademais, os acusados que constituírem o mesmo procurador e apresentarem defesa conjunta terão o mesmo prazo para se manifestarem nos autos, contado da citação que for efetivada por último, não cabendo mais prazo em dobro para tais $\operatorname{casos}^{97}$. Nos processos sancionadores instaurados em desfavor de múltiplos acusados, as defesas serão consideradas sigilosas e não serão fornecidas a terceiros ou a outros acusados até o encerramento do último prazo de apresentação de defesa ${ }^{98}$.

Após a apresentação da defesa, ou decorrido o prazo de 30 dias úteis sem que esta tenha sido apresentada, os autos serão encaminhados ao

\footnotetext{
${ }^{93}$ Art. 22. A citação poderá ser efetuada por ciência no processo, por meio eletrônico ou por via postal.

Art. $23, \S 1^{\circ}$. Não sendo possível a comunicação por meio eletrônico, a citação deverá ser realizada por via postal, com aviso de recebimento (...).

${ }_{94}$ Art. 21. Considera-se instaurado o processo administrativo sancionador com a citação dos acusados para apresentação de defesa: VI - o dever do acusado, ou de procurador por ele constituído, de se cadastrar no sistema de processo eletrônico existente na página da CVM na rede mundial de computadores para fins de acesso aos autos e posterior acompanhamento do andamento do processo.

${ }^{95}$ Art. 29 da Instrução CVM n 607.

${ }^{96}$ Art. $29, \S 3^{\circ}$ da Instrução CVM n 607.

${ }^{97}$ Art. 29, $\S^{\circ}$ da Instrução CVM n ${ }^{\circ} 607$.

${ }^{98}$ Art. 29, §5 $5^{\circ}$ da Instrução CVM n ${ }^{\circ} 607$.
} 
Colegiado para designação do relator por sorteio. Vale dizer que com a nova norma os processos serão sigilosos, cabendo ao relator analisar os pedidos de vista realizados por terceiros que não as partes ou seus procuradores ${ }^{99}$.

Nas sessões de julgamento compete um voto a cada diretor e as deliberações serão tomadas por maioria. Com a ICVM n ${ }^{\circ} 607$, o pedido de vista de um dos diretores não impede que os demais antecipem seus votos caso se sintam habilitados a fazê-lo, devendo os votos proferidos serem consignados em ata ${ }^{100}$. Na sessão em que o julgamento é retomado serão computados os votos já proferidos, ainda que o membro do colegiado que houver proferido o voto não compareça à sessão ou haja deixado o exercício do cargo, exceto nos casos de novos fatos ou provas relevantes, capazes de mudar significativamente o contexto decisório, vierem a integrar os autos, quando o acusado poderá arguir questão de ordem ${ }^{101}$.

A instrução também prevê critérios objetivos para a aplicação das penas além daqueles já previstos no art. 11 da Lei $n^{\circ}$ 6.385/1976. Dessa forma, o colegiado fixará inicialmente uma pena-base, aplicando na sequência as circunstâncias agravantes e atenuantes, bem como a causa de redução da pena, nessa ordem ${ }^{102}$. Conforme o Anexo 63 da instrução, as infrações são divididas em 5 grupos e as penas bases dos grupos vão de $\mathrm{R} \$ 300.000,00$ (trezentos mil reais) a $\mathrm{R} \$ 20.000 .000,00$ (vinte milhões de reais). Nos casos das penalidades de inabilitação temporária, suspensão da autorização ou registro para o exercício das atividades ou de proibição temporária de praticar determinadas atividades ou operações, a pena base deverá ser fixada em meses e não poderá ser superior a 10 (dez) anos ${ }^{103}$, enquanto que a pena base aplicável a pena da proibição temporária de atuar, direta ou indiretamente, em uma ou mais modalidades de operação no mercado de valores mobiliários não poderá ser superior a $5 \operatorname{anos}^{104}$.

\footnotetext{
${ }^{99}$ Art. 48 da Instrução CVM nº 607.

${ }^{100}$ Art. 57, $\S 2^{\circ}$ da Instrução CVM n 607.

${ }^{101}$ Art. 57, $\S 3^{\circ}$ e $5^{\circ}$ da Instrução CVM n 607.

102 Art. 62 da Instrução CVM nº 607.

103 Art. 63, $\S 3^{\circ}$ da Instrução CVM n ${ }^{\circ} 607$.

${ }^{104}$ Art. 63, \$4 $4^{\circ}$ da Instrução CVM n ${ }^{\circ} 607$.
} 
Após o estabelecimento da pena base, cada circunstância atenuante ou agravante representa um desconto ou acréscimo de $25 \%$ do valor da pena base respectivamente, ou do número de meses previsto na pena base, desprezando-se as frações ${ }^{105}$. São exemplos de circunstâncias agravantes ${ }^{106}$ a prática sistemática ou reiterada da conduta irregular, o elevado prejuízo causado e a expressiva vantagem auferida ou pretendida pelo infrator e de atenuantes ${ }^{107}$ a confissão do ilícito ou a prestação de informações relativas à sua materialidade e os bons antecedentes do infrator. É importante lembrar que o colegiado também considerará na dosimetria da pena as demais sanções relativas aos mesmos fatos, aplicadas definitivamente por outras autoridades $^{108}$.

A nova norma prevê, ainda, que, caso o dano financeiro a investidores ou acionistas seja integralmente reparado até o julgamento do processo no colegiado, a pena será reduzida de um a dois terços ${ }^{109}$.

Vale destacar, por fim, que as penalidades de suspensão, inabilitação e proibição somente serão aplicadas nos casos de infração grave, descritas no Anexo 64 da ICVM $607^{110}$, ou nos casos de reincidência.

Da decisão condenatória do colegiado, segundo o art. 70 da instrução, cabe recurso ao Conselho de Recursos do Sistema Financeiro Nacional, no prazo de 30 dias corridos, neste caso. Como já se afirmou no subcapítulo III.1 deste trabalho, o recurso com relação à decisão que aplica as penalidades

\footnotetext{
${ }^{105}$ Art. $65, \S \S 1^{\circ}$ e $2^{\circ}$ e art. $66, \S \S 3^{\circ}$ e $4^{\circ}$ da Instrução $n^{\circ} 607$.

106 Art. 65. São circunstâncias agravantes, quando não constituem ou qualificam a infração: I - a prática sistemática ou reiterada da conduta irregular; II - o elevado prejuízo causado; III - a expressiva vantagem auferida ou pretendida pelo infrator; IV - a existência de dano relevante à imagem do mercado de valores mobiliários ou do segmento em que atua; $\mathrm{V}$ - o cometimento de infração mediante ardil, fraude ou simulação; VI - o comprometimento ou risco de comprometimento da solvência do emissor; VII - a violação de deveres fiduciários decorrentes do cargo, posição ou função que ocupa; e VIII - a ocultação de provas da infração mediante ardil, fraude ou simulação.

${ }^{107}$ Art. 66. São circunstâncias atenuantes: I - a confissão do ilícito ou a prestação de informações relativas à sua materialidade; II - os bons antecedentes do infrator; III - a regularização da infração; IV - a boa-fé dos acusados; V - a adoção efetiva de mecanismos e procedimentos internos de integridade, auditoria e incentivo à denúncia de irregularidades, bem como a aplicação efetiva de códigos de ética e de conduta no âmbito da pessoa jurídica, avaliada por entidade pública ou privada de reconhecida especialização.

108 Art. 62, parágrafo único da Instrução CVM nº 607.

109 Art. 67 da Instrução CVM nº 607.

${ }^{110}$ Art. 64 da Instrução CVM nº 607.
} 
previstas nos incisos III a VII do art. 60 da Instrução serão recebidos com efeito devolutivo.

Por fim, cumpre dizer que a ICVM 607 trouxe também a possibilidade de celebração de acordo administrativo em processo de supervisão ${ }^{111}$ com pessoas que confessarem a prática de infração. $\mathrm{O}$ acordo pode prever a extinção punitiva dos infratores ou a redução de um a dois terços da penalidade aplicável mediante a efetiva, plena e permanente cooperação para a apuração de fatos que sejam úteis ao processo, em especial (i) a identificação de demais envolvidos na prática, quando couber; e (ii) a obtenção de informações e de documentos que comprovem a infração.

Após o exame do histórico do processo administrativo sancionador da CVM e da análise de seus requisitos processuais formais, no capítulo a seguir serão expostos os requisitos que a autarquia deve observar para instalação de um PAS, bem como os outros meios que podem ser utilizados pela CVM para cumprir seu papel de tutelar o mercado sem que seja preciso, no entanto, instaurar um processo administrativo sancionador.

111 Art. 92 da Instrução CVM nº 607. 


\section{IV - LIMITES AO PODER SANCIONADOR DA CVM}

Analisado o poder sancionador da CVM e a autonomia de sua aplicação, passa-se agora a analisar os limites que se impõem à atuação sancionadora da autarquia.

Para a doutrina administrativista clássica, são duas as finalidades da sanção administrativa. Se por um lado as sanções se destinam a incentivar os sancionados a cumprir as normas aplicáveis, por outro também têm como objetivo gerar um efeito aflitivo no infrator que sirva de exemplo para estimular os demais sancionados a cumprirem as normas.

Nesse sentido, Fábio Medina Osório prevê o efeito aflitivo como um elemento objetivo da sanção administrativa"112. Para o autor, sanção é "um mal, um castigo, e, portanto, implica um juízo de privação de direitos, imposição de deveres, restrição de liberdades, condicionamentos, ligados, em seu nascedouro e existência, ao cometimento (comprovado) de um ilícito administrativo"113.

Marcelo Trindade acrescenta que, no âmbito do mercado de valores mobiliários as sanções administrativas também se prestam a equilibrar o mercado, na medida em que o descumprimento das normas por alguns agentes pode causar um desequilíbrio das relações no mercado. Dessa forma, o poder sancionador da CVM possui 3 finalidades: reprimir a conduta indevida, estimular o cumprimento das normas pelos participantes e manter o equilíbrio do mercado ${ }^{114}$.

Tal poder, contudo, não deve ser ilimitado. A atuação sancionadora da CVM encontra limites tanto com relação aos sujeitos aos quais pode incidir tal poder, como também em relação ao tempo que a autarquia dispõe para aplicar a sanção a determinado participante por suposto ato irregular. Além

\footnotetext{
${ }^{112} \mathrm{O}$ autor destaca que apesar do caráter aflitivo das sanções administrativas ser um elemento comum com as sanções penais, nem todas as sanções administrativas apresentam íntima relação com estas últimas. A multa, por exemplo, está muito mais próxima do Direito Civil do que do Direito Penal. OSÓRIO, Fábio Medina. Op. Cit. p. 101.

${ }^{113}$ Ibid. p. 101.

114 TRINDADE, Marcelo. In: A Lei das S.A. em seus 40 anos. VENANCIO FILHO, Alberto; LOBO, Carlos Augusto da Silveira; e ROSMAN, Luiz Alberto Colonna (coord). Op. Cit. 496.
} 
disso, o processo administrativo sancionador encontra limites formais na aplicação dos princípios constitucionais do direito punitivo.

\section{IV.1. Sujeitos sobre os quais incide o poder sancionador da CVM}

$\mathrm{O}$ inciso $\mathrm{V}$ do art. $9^{\circ}$ da Lei $\mathrm{n}^{\circ} 6.385 / 1976$ delimita os destinatários do poder sancionador da autarquia: administradores, membros do conselho fiscal e acionistas de companhias abertas, intermediários e demais participantes do mercado de valores mobiliários. A primeira observação que se faz é relativa aos acionistas e administradores das companhias fechadas. Quanto a eles, o poder sancionador da autarquia não incide e, conforme afirma Alexandre Tavares Guerreiro, "não há extensão possível desse campo de incidência"115.

Discussão relevante sobre o tema diz respeito à possibilidade de a CVM sancionar membros de comitês estatutários. Apesar destes terem sido incluídos no rol das pessoas sujeitas à instauração de processo administrativo sancionador no art. $3^{\circ}$ da Instrução $n^{\circ} 607^{116}$, entendo que tal inclusão ultrapassa a previsão do inciso $\mathrm{V}$ do art. $9^{\circ}$ da Lei $\mathrm{n}^{\mathrm{o}}$ 6.385/1976 ${ }^{117}$. Nesse sentido, a Instrução CVM no 607 incluiu sob a tutela do poder sancionador da CVM sujeitos que a lei não previu, indo contra o princípio constitucional da legalidade.

É bem verdade que o art. 160 da Lei $n^{\circ} 6.404 / 1976^{118}$ prevê que as normas da Seção IV do Capítulo VII da lei referentes às responsabilidades dos administradores são aplicáveis aos membros de quaisquer órgãos estatutários com funções técnicas ou consultivas. Entretanto, essa

\footnotetext{
${ }^{115}$ GUERREIRO, José Alexandre Tavares. Op. Cit. p. 67.

${ }^{116}$ Art. $3^{\circ}$ Caberá às superintendências a investigação de infrações administrativas, a instrução processual e a instauração de processo administrativo sancionador destinados a apurar atos ilegais e práticas não equitativas de administradores, membros do conselho fiscal, os integrantes de comitê estatutário e acionistas de companhias abertas, dos intermediários e dos demais participantes do mercado.

$117 \mathrm{~V}$ - apurar, mediante processo administrativo, atos ilegais e práticas não eqüitativas de administradores, membros do conselho fiscal e acionistas de companhias abertas, dos intermediários e dos demais participantes do mercado

${ }^{118}$ Art. 160. As normas desta Seção aplicam-se aos membros de quaisquer órgãos, criados pelo estatuto, com funções técnicas ou destinados a aconselhar os administradores.
} 
equiparação não me parece ser razoável para fins da possibilidade de instauração de processo administrativo sancionador, pois, como já se falou ao longo deste trabalho, o poder sancionador atinge direitos valiosos dos indivíduos e pode resultar em sanções extremamente aflitivas para os apenados.

A inclusão de membros de comitês estatutários na Instrução CVM n ${ }^{\circ}$ 607 surpreende não apenas por não encontrar embasamento legal, como porque alguns meses antes da edição da Instrução, a CVM discutiu questão semelhante em um caso concreto, relacionado à possibilidade de a autarquia sancionar o presidente de assembleia geral, como membro componente do órgão estatutário, em sede de um PAS.

Trata-se do PAS CVM n ${ }^{\circ}$ RJ2013/2759, julgado em 20 de fevereiro de 2018, no qual a SEP alegou que o presidente da assembleia geral da Aliança Participações S.A. não poderia ter acolhido os votos do acionista controlador da companhia na eleição em separado para eleger membro do conselho físcal dos acionistas preferencialistas e por isso deveria ser responsabilizado ${ }^{119}$.

O relator Henrique Machado, que sustentou o voto vencedor, entendeu que o presidente da mesa não figura no rol de sujeitos passivos da ação sancionadora da CVM previsto no art. $9^{\circ}$, inciso V da Lei ${ }^{\circ}$ 6.385/1976 e que, portanto, a autarquia não teria competência para instaurar processo administrativo contra ele. Destaca-se que o diretor manifestou entendimento de que, mesmo no caso de o presidente da assembleia ser um administrador, membro do conselho ou acionista, por exemplo, a ação sancionadora da CVM não poderia recair sobre esses sujeitos na qualidade de presidente da assembleia (ressalvando que eles "não se demite[m], ainda que temporariamente, das obrigações que possue[m] em razão de sua[s] função[ões] e não se elide[m] das responsabilidades a ela[s] inerentes).

O diretor também afirmou que a expressão "demais participantes do mercado" contida na parte final do inciso V do artigo $9^{\circ}$ da Lei 6.385/1976

\footnotetext{
${ }^{119}$ Vale dizer que a SEP ignorou o entendimento do parecer da PFE no sentido de que o presidente da mesa responderia apenas pelo descumprimento de atribuições formais, por exemplo, naquilo que diz respeito aos art. 126, 127 e 130 da Lei 6.404/1976.
} 
não deve incluir o presidente da mesa de assembleia geral de companhia aberta. Isso porque, segundo ele, ainda que esta expressão seja de conteúdo aberto, tal fato "não confere, e nem poderia conferir, à CVM o poder de instaurar processo sancionador em desfavor de qualquer sujeito, face à constitucional sujeição do poder punitivo do Estado aos termos da Lei”. Ainda, afirma Henrique Machado que os critérios de relevância ou de expressa previsão na Lei $n^{\circ}$ 6.404/1976 não definem o conteúdo da expressão "demais participantes do mercado". Concluiu o diretor afirmando que a existência de um relacionamento do sujeito com a companhia aberta não atrai, por si só, a competência da CVM.

Entendendo de forma diversa, Gustavo Borba votou a favor da responsabilização do presidente da mesa. Para Borba, a atuação sancionadora da autarquia não poderia ser afastada dos membros ou componentes de órgãos estatutários:

\begin{abstract}
“(...) considerando todas as nuances da Lei 6.385/76 (...) não se deve afastar a competência da CVM em relação aos órgãos estatutários (e componentes destes) que exerçam com autonomia, mesmo que relativa, no âmbito da estrutura orgânica essencial da companhia aberta, funções relevantes previstas na Lei 6.404/76, uma vez que entendimento diverso acabaria por inviabilizar que a autarquia exercesse adequadamente sua atribuição de assegurar o funcionamento eficiente e regular do mercado. Uma interpretação demasiadamente restritiva da expressão "demais participantes do mercado" impediria a fiscalização pela CVM de órgãos e agentes institucionais que exercem funções extremamente relevantes e delicadas por determinação da Lei $6.404 / 76$, mas que não foram explicitamente indicados no inciso $\mathrm{V}$ do art. $9^{\circ}$ da Lei 6.385/76, como, por exemplo, o agente fiduciário, ao qual, por essa linha restritiva, não poderiam ser aplicadas as punições previstas nos incisos do art. $11(\ldots) "$
\end{abstract}

Apesar da divergência manifestada pelo diretor Gustavo Borba, essa decisão do Colegiado representa a interpretação da autarquia quanto ao rol art. $9^{\circ}, \mathrm{V}$ da Lei $\mathrm{n}^{\circ}$ 6.385/1976. Se por um lado a autarquia andou bem neste julgado ao dar interpretação restritiva ao rol do referido artigo da Lei de Mercado de Capitais, por outro, conforme já se destacou acima, é interessante notar que meses depois dessa decisão a própria CVM interpreta de forma ampla a previsão do art. $9^{\circ}, \mathrm{V}$ da lei e inclui no rol de indivíduos sujeitos à atividade sancionadora da autarquia membros de comitês estatutários. 
A interpretação ampliativa do rol do art. $9^{\circ}, \mathrm{V}$ gera grande insegurança jurídica aos participantes do mercado, especialmente porque este artigo representa um limite objetivo ao poder sancionador da autarquia.

\section{IV.2. Prescrição}

O instituto da prescrição "é uma criação da ordem jurídica que tem por finalidade precípua o encerramento de demandas que não foram implementadas a tempo"120. A prescrição gera segurança jurídica na medida em que os sujeitos não ficam eternamente subordinados à vontade do Estado de exercer seu direito punitivo. Caso o Poder Público se mantenha inerte por determinados períodos de tempo, tal inércia gera a prescrição.

Assim é que a regra no nosso ordenamento jurídico é a limitação temporal para ação, sendo a imprescritibilidade exceção. Vale dizer que a prescrição se coaduna com o princípio da celeridade processual previsto no art. 5 $5^{\circ}$ LXXVIII da Constituição da República de $1988^{121}$ e que incide sobre o processo administrativo sancionador.

Nesse sentido, a prescrição se apresenta como um limite temporal ao jus puniendi da CVM na medida em que a autarquia só pode exercer seu poder sancionador sobre condutas que ocorreram durante um período determinado de tempo.

Sobre o tema, em 1999 foi editada a Lei $n^{\circ} 9.873$ que estabelece prazo de prescrição para o exercício da ação punitiva pela Administração Pública Federal, direta e indireta. Passados 20 anos da criação da lei, ainda há na doutrina e na jurisprudência um leque de dúvidas a respeito da interpretação dos dispositivos da lei, especialmente porque "ao tentar elaborar um conjunto de normas que valessem para todas as espécies de processo administrativo federal, o legislador acabou por criar um conjunto genérico, que não leva em

\footnotetext{
${ }^{120}$ LORIA, Eli. A prescrição do exercício da ação punitiva no âmbito dos processos administrativos sancionadores da CVM. In: Revista de Direito Bancário e do Mercado de Capitais. Vol. 82/2018. pp. 53-79.

${ }^{121}$ LXXVIII - a todos, no âmbito judicial e administrativo, são assegurados a razoável duração do processo e os meios que garantam a celeridade de sua tramitação.
} 
consideração as minúcias e as características de cada uma dessas espécies" $" 122$.

Feita essa ressalva, passo à análise da referida lei. $\mathrm{O}$ art. $1^{\circ}$, caput ${ }^{123}$ prevê o prazo para a prescrição geral da ação punitiva da Administração Pública Federal, que é de 5 anos contados da data da prática do ato ou, no caso de infração permanente ou continuada, do dia em que tiver cessado.

Já o $§ 1^{\circ}$ desse artigo prevê que ocorre a prescrição "no procedimento administrativo paralisado por mais de três anos, pendente de julgamento ou despacho, cujos autos serão arquivados de ofício ou mediante requerimento da parte interessada". Assim, a lei estabeleceu duas prescrições diferentes: a prescrição geral, cujo prazo é de 5 anos, e a prescrição intercorrente, com prazo de 3 anos.

$\mathrm{O}$ art. $2^{\circ}$ da lei estipula os atos que interrompem a contagem da prescrição, conforme se vê abaixo:

Art. 2º. Interrompe-se a prescrição da ação punitiva:

I - pela notificação ou citação do indiciado ou acusado, inclusive por meio de edital;

II - por qualquer ato inequívoco, que importe apuração do fato;

III - pela decisão condenatória recorrível.

IV - por qualquer ato inequívoco que importe em manifestação expressa de tentativa de solução conciliatória no âmbito interno da administração pública federal.

Um dos pontos que até hoje provoca discussões na doutrina e nos diferentes órgãos da Administração diz respeito aos marcos a partir dos quais os prazos prescricionais referidos no art. $1^{\circ}$, caput e $\S 1^{\circ}$ da Lei $n^{\circ} 9.873 / 1999$ são contados. A corrente majoritária da doutrina defende que o prazo da prescrição geral, de 5 anos, incide desde a data dos fatos apurados, enquanto que o da prescrição intercorrente, de 3 anos, ocorreria somente a partir da intimação do acusado ${ }^{124}$. Fazem parte desse posicionamento majoritário

\footnotetext{
122 LORIA, Eli. Op. Cit. pp. 53-79.

${ }^{123}$ Art. $1^{\circ}$. Prescreve em cinco anos a ação punitiva da Administração Pública Federal, direta e indireta, no exercício do poder de polícia, objetivando apurar infração à legislação em vigor, contados da data da prática do ato ou, no caso de infração permanente ou continuada, do dia em que tiver cessado

${ }^{124}$ Vide voto do relator Luiz Anotnio de Sampaio Campos no PAS CVM no 22/94, julgado em 15.04.2004: "Com efeito, não se aplica a hipótese de prescrição intercorrente antes de haver a acusação formal, com o estabelecimento do processo administrativo. Pretender o contrário
} 
Alexandre Pinheiro dos Santos, Fábio Medina Osório, Julya Sotto Mayor Wellisch ${ }^{125}$, Nelson Eizirik, Ariádna Gaal, Flávia Parente e Marcus de Freitas Henriques. Estes últimos 4 autores entendem que:

\begin{abstract}
"No que diz respeito à primeira questão (o momento no qual a interrupção passa a ocorrer), na medida em que na fase de investigação inexistem os "acusados" ou "indiciados" de que trata o art. $2^{\circ}$, inciso I, da Lei $n^{\circ} 9.873 / 1999$, e tendo em vista que o processo administrativo sancionador apenas terá início com a notificação ou a intimação daqueles, é inconteste que as causas interruptivas somente poderão ser invocadas após a sua instauração" $" 126$.
\end{abstract}

Minoritariamente, entende-se que a prescrição intercorrente pode ocorrer mesmo antes da abertura do processo administrativo sancionador. $\mathrm{O}$ ex diretor da CVM Eli Loria defende tal posição, alegando que não há, na literalidade do $\S 1^{\circ}$ do artigo $1^{\circ}$, qualquer elemento que indique que a palavra "procedimento" utilizada pelo legislador deva ser entendida como "processo administrativo sancionador" ou "processo administrativo punitivo"127.

Assim, para a corrente minoritária, o legislador previu duas hipóteses: de um lado, quando ocorre uma conduta supostamente irregular, o Estado adquire pretensão punitiva que se encerra em 5 anos, independentemente da abertura ou não de PAS (admitidos, claro, os fatos interruptivos desse prazo). De outro, o Estado não pode deixar o procedimento administrativo paralisado por mais de 3 anos, pendente de julgamento ou despacho. Nesse caso o termo procedimento deve abarcar todos os atos da CVM na fase investigativa, isto é, na qual a autarquia já esteja investigando os fatos, mas ainda não ocorreu a notificação do acusado.

\footnotetext{
significaria uma inversão das regras, no sentido de que o prazo que a lei dá (salvo nas hipóteses de interrupção naturalmente) para apurar e acusar, que é de 5 anos, seria reduzido e passaria a ser de 3 anos".

125 DOS SANTOS, Alexandre Pinheiro; OSÓRIO, Fábio Medina; WELLISCH, Julya Sotto Mayor. Op. Cit. p. 227.

${ }^{126}$ EIZIRIK, Nelson; GAAL, Ariádina; Parente, Flávia; DE FREITAS HENRIQUES, Marcus. Mercado de Capitais - Regime Jurídico. Rio de Janeiro: Renovar, 2008. p. 320.

${ }^{127}$ LORIA, Eli. Op. Cit. pp. 53-79.
} 
No mesmo sentido que Loria, veja-se o voto vencedor no Recurso $n^{\circ}$ 14.400 do conselheiro relator Sérgio Cipriano dos Santos do Conselho de Recursos do Sistema Financeiro Nacional, julgado em junho de 2018:

\begin{abstract}
"Imaginemos que a Administração Pública Federal tomou ciência de um ato que poderia constituir uma infração seis meses após a sua ocorrência, constituiu um procedimento de avaliação desse ato, mas os autos relativos a esse procedimento ficam sem decisão ou qualquer despacho nos três anos seguintes, é forçoso o reconhecimento da prescrição intercorrente. Não importa que ainda não houvesse a fluência total do prazo de cinco anos referentes à prescrição ordinária, mesmo que dentro do prazo de cinco anos da ocorrência do fato se constitua um processo administrativo punitivo relativo àquela infração, se a administração pública estava ciente do ato, e a análise do mesmo não sofreu nenhum impulso por mais de três anos, se configuraria a ocorrência da prescrição intercorrente".
\end{abstract}

Sérgio Cipriano também entende que os dois prazos prescricionais são válidos tanto antes quanto depois da abertura do PAS e que por isso não incidem sobre tais prazos condições de interrupção idênticas. Para o conselheiro, a paralisação relativa à prescrição intercorrente "se configuraria pela ausência de julgamento ou despacho pelo lapso de tempo de três anos", sendo despacho qualificado como algo que "que impulsione o procedimento a um desfecho". Assim é seu entendimento:

\footnotetext{
"A priori, não há na lei uma indicação que alguma das prescrições só existe antes ou depois do PAS. Pode-se argumentar que a punição só pode decorrer de um processo e do correspondente contraditório, contudo isso seria limitar o escopo da lei ao período posterior à abertura do PAS, inclusive a prescrição de 5 anos, mas o art. $2^{o}$ expressamente trata de atos de apuração, que são atos que logicamente precedem a abertura de um processo sancionador. Naturalmente não se pode conceber o argumento de que os atos de apuração previstos no inciso II do art. $2^{\circ}$ da Lei $n^{\circ}$ 9.873, de 1999, só tenham efeito após a instauração do PAS (...)”.
}

Além da discussão sobre quais são os marcos temporais a partir dos quais decorrem os prazos previstos no art. $1^{\circ}$, caput e $\S 1^{\circ}$, a doutrina também é conflitante a respeito de quais atos ensejam a interrupção desse prazo. A expressão "ato inequívoco" presente no inciso II do art. $2^{\circ}$ da Lei $n^{\circ}$ 9.873/1999, por carregar alto grau de subjetividade, gera interpretações diferentes. 
O envio de um processo de uma área da CVM a outra, por exemplo, pode impulsionar as investigações do processo e de fato configurar um ato inequívoco, ou pode ser que a área que receba o processo não contribua efetivamente para o desfecho do processo $^{128}$.

Nesse sentido, Eizirik, Ariádna, Flávia e Marcus sustentam que "as expressões ‘enigmáticas' existentes na norma possibilitariam que os órgãos julgadores do mercado, mediante o alargamento do conceito das causas de interrupção, 'adiem' indevidamente a contagem dos prazos prescricionais" 129 .

Discute-se a necessidade de o acusado ter conhecimento dos atos inequívocos para que eles sejam considerados como aptos para interromper a prescrição. Nesse ponto, o entendimento já pacificado da CVM é no sentido de que os atos inequívocos de apuração não precisam ser bilaterais, isto é, não precisam ser levados ao conhecimento dos indiciados ou acusados para que ocorra a interrupção da prescrição. Nesse sentido, veja-se o voto do ex diretor Marcelo Trindade no âmbito do PAS CVM n 2002/1823:

"A meu sentir, a lei exige apenas a prática de um ato administrativo inequívoco, entendendo-se por ato inequívoco - até mesmo em virtude da regra do sigilo dos atos de investigação - não o ato notificado, o ato público, mas sim o ato que deixa comprovação. Não é ato secreto, é ato tomado nos autos, deixando prova inequívoca de sua existência e finalidade. Este ato, no caso dos autos, foi feito praticado com observância das formalidades legais, deixando marca inequívoca de sua existência".

No âmbito do CRSFN, há uma corrente minoritária que se filia ao entendimento de que os atos internos e preliminares, pelo fato de serem unilaterais, ou seja, por não contarem com a ciência de ambas as partes não teriam condão para interromper o prazo prescricional ${ }^{130}$.

\footnotetext{
128 LORIA, Eli. Op. Cit. pp. 53-79.

129 EIZIRIK, Nelson; GAAL, Ariádina; Parente, Flávia; DE FREITAS HENRIQUES, Marcus. Op. Cit. p. 321.

${ }^{130}$ Vide voto do relator André Luiz Dumortout de Mendonça no Recurso no 5957, julgado em 23.02. 2005: "Outrossim, não houve ato inequívoco capaz de interromper o prazo da prescrição, pois, no meu entender, o ato inequívoco, previsto na Lei, há de ser aquele pelo qual a parte tenha tomado conhecimento das apurações que estejam sendo levadas a efeito, quer através de algum expediente a ela dirigido, como carta, telegrama ou outras formas de comunicados, ou, então, através de fatos
} 
O posicionamento majoritário, contudo, entende que o processo administrativo é, em sua essência, sigiloso, e que os atos praticados no intuito de dar prosseguimento ao processo de investigação e esclarecimento dos fatos podem ser considerados "atos inequívocos" e, conforme disposto no art. $2^{\circ}$, inciso II, Lei $n^{\circ} 9.873 / 1999$, seriam suficientes para interromper o prazo prescricional.

Ainda sobre a discussão do que configuraria um "ato inequívoco", o Tribunal Regional Federal da $2^{\mathrm{a}}$ Região já decidiu que despachos de mero expediente não caracterizam a inércia da Administração e que interrompem o prazo da prescrição intercorrente ${ }^{131}$.

A jurisprudência da CVM e do CRSFN também considera causa de interrupção do prazo da prescrição trienal a troca de relator decorrente de fim do mandado do anterior, "sob argumento de que esta troca não é mera 'mudança de mesa' do processo, mas sim o encaminhamento necessário ao seu desfecho"132.

Assim, vê-se que a orientação dos nossos tribunais não é pacífica no que diz respeito à interpretação da expressão "atos inequívocos", o que gera insegurança jurídica entre os sujeitos sobre os quais incide poder punitivo da Administração Pública. Com relação à necessidade de "bilateralidade", a questão está mais próxima do consenso e os tribunais tendem a considerar que os atos não precisam ser bilaterais, mas não podem ser 'secretos', isto é, devem ser sempre documentados nos autos do processo.

Há, ainda, discussão a respeito da quantidade de vezes que o prazo prescricional pode ser interrompido. Minoritariamente, entende-se que se todo e qualquer ato inequívoco da Administração pudesse interromper o prazo a qualquer tempo seria reconhecida verdadeira hipótese de

\footnotetext{
públicos e notórios, referentes à atividade desenvolvida pela administração, com relação à matéria que poderá dar ensejo à instrução do competente processo administrativo".

131 TRF da 2a Região, Sétima Turma Especializada, Processo n. 2004.5101.0140181, Rel. Des. Reis Friede, julgado em 02.03.2011.

${ }^{132}$ Vide voto do diretor relator Henrique Machado no âmbito do PAS CVM nº 2013/2759, julgado em 20.02.2018.
} 
imprescritibilidade da pretensão punitiva ${ }^{133}$. A segurança jurídica dos regulados não pode ficar à mercê da burocracia estatal e da troca de ofícios e informações, nem sempre necessárias ou úteis ao processo, entre órgãos ou setores de um mesmo órgão ${ }^{134}$.

Apesar das discussões a respeito da aplicação dos dispositivos da Lei n 9.873/1999, fica evidente que tanto a prescrição geral quanto a prescrição intercorrente representam um limite temporal ao processo administrativo sancionador da CVM. A primeira impede que a autarquia disponha de uma espada eternamente imposta sobre as cabeças dos regulados, o que em nada seria benéfico para a segurança jurídica do mercado. A segunda impõe limite à duração do processo administrativo sancionador, para que seja razoável e atenda ao previsto no art. 5º LXXVIII da Constituição da República de 1988.

\section{IV.3. Princípios constitucionais do direito punitivo}

Muito se discute no mundo jurídico sobre o significado, o alcance, a funcionalidade e a evolução dos princípios jurídicos ao longo da história e diversas são as teorias sobre essa matéria, o que demonstra sua complexidade. O presente trabalho não pretende explorar ou mesmo apresentar as diversas teorias dos princípios existentes, mas apenas classificar os princípios constitucionais do direito punitivo didaticamente, a fim de demonstrar seu papel na imposição de limites ao poder sancionador da Administração pública e, mais especificamente da CVM.

Assim, no âmbito deste trabalho, os princípios serão considerados como normas gerais que compõem o nosso ordenamento jurídico e que disciplinam

\footnotetext{
${ }^{133}$ Veja-se, por exemplo, o PAS CVM no 12/20113, rel. Gustavo Borba, julgado em 24.05.2016: “Considero, contudo, não ser essa a melhor interpretação da Lei $n^{\circ}$ 9.873/99, uma vez que, seguindo esse raciocínio, o prazo para instauração do PAS poderia ser sucessiva e indefinidamente interrompido, em razão de diversos 'atos inequívocos', o que obstaria a própria razão de ser dos institutos da prescrição e da decadência, que é a pacificação social”.

${ }^{134}$ LORIA, Eli. Op. Cit. pp. 53-79.
} 
uma série indeterminada de situações, isto é, emanam efeitos por todo o sistema jurídico, sem objetivar regular apenas hipóteses específicas ${ }^{135}$.

Os princípios “condiciona[m] a criação, a interpretação e aplicação da regra que lhe dá concreção. Serve[m] o[s] princípio[s], portanto, como fundamento das demais normas jurídicas, que a ele[s] estão subordinadas"136/137.

Alguns princípios constitucionais representam a estrutura básica da ordem constitucional, ou seja, são a coluna vertebral do ordenamento e sobre os quais os subprincípios se apoiam. A tais princípios basilares da ordem constitucional são atribuídas nomenclaturas diversas (princípios constitucionais estruturantes, princípios político-constitucionais ou princípios constitucionais fundamentais), mas, independentemente da tipologia, os autores concordam que tais princípios "representam as premissas fundamentais adotadas pelo legislador constituinte" ${ }^{138}$.

Na Constituição Federal de 1988, o Estado Democrático de Direito é um princípio constitucional fundamental, conforme se vê do caput do art. $1^{\mathrm{o}}$ da carta magna ${ }^{139}$. Tal princípio pressupõe não só a submissão à lei e à jurisdição (aspecto formal), como também a garantia de todos os direitos fundamentais dos indivíduos (aspecto substancial).

Para Rafael Munhoz de Mello, “o princípio constitucional do Estado de Direito e seus subprincípios formam a base do regime jurídico punitivo,

\footnotetext{
135 MUNHOZ DE MELLO, Rafael. Princípios Constitucionais do Direito Administrativo Sancionador - As Sanções Administrativas à Luz da Constituição Federal de 1988. São Paulo: Malheiros, 2007. p. 88.

136 Ibid. p. 87.

${ }^{137}$ Sobre os princípios, Fábio Medina Osório destaca: “(...) não está abandonada a ideia de que os princípios ocupariam um lugar de notável importância e superioridade no ordenamento jurídico. Esta foi uma função clássica dos princípios, ao assumirem papéis mais ambiciosos de legitimação de uma nova lógica de produção jurídica. Agora, longe de abdicar dessa funcionalidade, os princípios assumem com radicalidade toda uma nova simbologia de poder, sendo este o de fundamentar e organizar o sentido do discurso jurídico. Não há discurso que não pretenda, ou não deva pretender, justificar-se e legitimar-se em princípios, ainda que a fonte mais direta e imediata das soluções resida nas regras. Por isso, a fundamentação das sentenças e acórdãos mais sofisticados recorre, não raramente, ao apelo dos princípios, mesmo que os fundamentos mais diretos repousem em regras bem claras e contundentes". OSÓRIO, Fábio Medina. Op. Cit. p. 167. ${ }^{138}$ MUNHOZ DE MELLO, Rafael. Op. Cit. p. 90.

139 Art. $1^{\circ}$ A República Federativa do Brasil, formada pela união indissolúvel dos Estados e Municípios e do Distrito Federal, constitui-se em Estado Democrático de Direito (...).
} 
aplicado às manifestações do poder punitivo estatal, seja ele exercido pela Administração Pública (sanções administrativas retributivas), seja ele exercido pelo Poder Judiciário (sanções penais)"140.

Tal regime jurídico punitivo é composto, por sua vez, pelos princípios constitucionais do devido processo legal, legalidade, tipicidade, irretroatividade, culpabilidade, non bis in idem e presunção de inocência.

Lembra-se, também, que incidem sobre a CVM os princípios gerais da Administração Pública previstos no art. 37 da Constituição Federal, quais sejam, os princípios de legalidade, impessoalidade, moralidade, publicidade e eficiência.

A própria ICVM n 607 prevê que, nos procedimentos de que trata a Instrução:

“(...) a CVM observará os princípios da legalidade, da finalidade, da motivação, da razoabilidade, da proporcionalidade, da moralidade, da ampla defesa, do contraditório, da segurança jurídica, do devido processo legal, da presunção de inocência, da celeridade processual, do interesse público, da impessoalidade, da eficiência e da publicidade".

Anote-se, por fim, que o art. $5^{\circ}, \S 2^{\circ}$ da Constituição Federal de $1988^{141}$ prevê que os princípios devem ser interpretados de forma conjunta.

\section{a. Devido processo legal}

Ao contrário do que ocorre nas relações privadas, a formação da vontade Estatal não é livre, pois está subordinada à busca pelo interesse público e vinculada a normas e princípios jurídicos que disciplinam o modo de formação do ato a ser editado ${ }^{142}$. Assim, o princípio do devido processo legal incide sobre todas as atividades desenvolvidas pela Administração Pública, "que está obrigada a observar certas garantias processuais sempre

\footnotetext{
${ }^{140}$ MUNHOZ DE MELLO, Rafael. Op. Cit. p. 102.

${ }^{141} \S 2^{\circ}$ Os direitos e garantias expressos nesta Constituição não excluem outros decorrentes do regime e dos princípios por ela adotados, ou dos tratados internacionais em que a República Federativa do Brasil seja parte.

${ }^{142}$ MUNHOZ DE MELLO, Rafael. Op. Cit. p. 223.
} 
que seu agir atinja a esfera dos particulares". De fato, dispõe a Constituição no inciso LIV do seu art. $5^{\circ}$ que "ninguém será privado da liberdade ou de seus bens sem o devido processo legal", norma que deve ser aplicada a qualquer manifestação da função administrativa do Estado, não só ao processo sancionador. Para o objetivo do presente trabalho, contudo, cabe analisar o devido processo legal na sua esfera relacionada à atividade sancionadora da Administração Pública.

Via de regra, os atos do Poder Público que possam restringir a liberdade ou a propriedade devem ser precedidos por um processo que permita ao interessado efetiva participação na formação do ato que será praticado ${ }^{143}$. Para Fábio Medina Osório, isso se materializa se o processo obedecer aos seguintes passos: notificação ou citação do imputado, garantia dos direitos de defesa, com abertura de possibilidade de o imputado manifestar-se, por escrito ou oralmente, e resolução motivada por parte de autoridade competente e imparcial ${ }^{144}$. A doutrina, contudo, não é unânime ao expor as garantias processuais do processo legal, havendo divergências a respeito da extensão de tais garantias ${ }^{145}$.

No Brasil, os direitos de defesa referidos por Fábio Medina Osório estão principalmente ligados ao direito ao contraditório e à ampla defesa, que embora decorram do devido processo legal, estão dispostos de forma independente no art. $5^{\circ}$, LV da Constituição da República. Rafael Munhoz de Mello resume tais princípios no binômio "informação/reação", o que significa que o acusado deve ser informado da existência do processo e de todos os atos praticados ao longo do seu curso, permitindo sua reação e a apresentação de novas alegações e $\operatorname{provas}^{146 / 147}$.

\footnotetext{
${ }^{143}$ Ibid. p. 221.

${ }^{144}$ OSÓRIO, Fábio Medina. Op. Cit. p. 179.

${ }^{145}$ Para Nelson Nery Jr., por exemplo o rol das garantias consiste nos seguintes subprincípios: (i) isonomia; (ii) juiz e promotor natural; (iii) inafastabilidade do controle jurisdicional; (iv) contraditório; (v) proibição da prova ilícita; (vi) publicidade dos atos processuais; (vii) duplo grau de jurisdição; (viii) motivação das decisões judiciais. NERY JR, Nelson. Princípios do processo civil na Constituição Federal. São Paulo: RT, 2000. p. 42.

${ }^{146}$ MUNHOZ DE MELLO, Rafael. Op. Cit. p. 229.

${ }^{147} \mathrm{O}$ autor destaca: "Os princípios, aplicáveis a toda espécie de processo por expressa dicção constitucional, exigem a comunicação aos interessados da existência e dos termos do processo, bem
} 
A Lei $n^{\circ}$ 9.784/1999, que regula o processo administrativo no âmbito da Administração Pública federal e visa "à proteção dos direitos dos administrados e ao melhor cumprimento dos fins da Administração" 148 dedicou diversos artigos aos princípios da ampla defesa e do contraditório, destacando-se o art. $2^{\text {o149 }}$, que os coloca entre os princípios que devem ser observados pela Administração Pública. O inciso $\mathrm{X}$ deste artigo ainda garante ao acusado "direitos à comunicação, à apresentação de alegações finais, à produção de provas e à interposição de recursos", direitos por meio dos quais são exercidos o contraditório e a ampla defesa.

Os incisos II e III do art. $3^{\circ}$ da referida lei atendem concretamente ao binômio informação/reação, pois o inciso II prevê que o administrado tem direito à "ter ciência da tramitação dos processos administrativos em que tenha a condição de interessado, ter vista dos autos, obter cópias de documentos neles contidos e conhecer as decisões proferidas" e o inciso III dá ao acusado o direito de "formular alegações e apresentar documentos antes da decisão, os quais serão objeto de consideração pelo órgão competente". Ainda, o inciso IV do art. $3^{\circ}$ confere ao administrado o direito à defesa técnica, isto é, o de ser assessorado por advogado.

A lei ainda prevê o direito de produzir $\operatorname{provas}^{150}$, que só podem ser indeferidas "quando sejam ilícitas, impertinentes, desnecessárias ou protelatórias" e "mediante decisão fundamentada"151. Caso as provas estejam

como a concessão de oportunidade para que sejam apresentadas alegações e produzidas provas previamente à decisão. Exigem mais: todos os atos praticados no curso do processo devem ser comunicados às partes, dando-se-lhes oportunidade de oferecer novas alegações, contraditando as que tenham sido apresentadas pela outra parte ou terceiros. Enfim, a ampla defesa e o contraditório não se reduzem à fase inicial do processo, sendo aplicáveis durante todo seu trâmite, até a decisão final”. Ibid. p. 228.

148 Art. $1^{\circ}$. Esta Lei estabelece normas básicas sobre o processo administrativo no âmbito da Administração Federal direta e indireta, visando, em especial, à proteção dos direitos dos administrados e ao melhor cumprimento dos fins da Administração.

149 Art. $2^{\circ}$. A Administração Pública obedecerá, dentre outros, aos princípios da legalidade, finalidade, motivação, razoabilidade, proporcionalidade, moralidade, ampla defesa, contraditório, segurança jurídica, interesse público e eficiência.

${ }^{150}$ Art. 38. O interessado poderá, na fase instrutória e antes da tomada da decisão, juntar documentos e pareceres, requerer diligências e perícias, bem como aduzir alegações referentes à matéria objeto do processo.

151 Art. 38, §2 . Somente poderão ser recusadas, mediante decisão fundamentada, as provas propostas pelos interessados quando sejam ilícitas, impertinentes, desnecessárias ou protelatórias. 
em poder da Administração Pública, a fim de evitar que o acusado dependa do órgão administrativo, o art. 37 prevê que "o órgão competente para a instrução proverá, de ofício, à obtenção dos documentos ou das respectivas cópias". Cabe mencionar, por fim, o art. 44 da lei que garante ao acusado o direito de apresentar alegações finais, isto é, sua manifestação quando todos os atos de instrução já tiverem sido praticados.

Todas essas previsões legais advêm das garantias processuais do devido processo legal. Importante observação que se faz, contudo, diz respeito à existência do aspecto material do devido processo legal, comumente lembrado apenas no seu aspecto processual. Assim, para além das garantias processuais supracitadas, o princípio também possui um aspecto substancial. As garantias formais do devido processo legal, na realidade, "constituem os primeiros e fundamentais passos na delimitação dos direitos substanciais em jogo" 152 . Fábio Medina Osório, após explicar o due processo of law do direito americano, que corresponde ao devido processo legal no Brasil, afirma:

\begin{abstract}
"Mais do que proibir a arbitrariedade dos Poderes Públicos, a cláusula do due processo of law, no Direito brasileiro, há de produzir uma série de fundamentais consequências no plano da atividade sancionadora do Estado, emergindo aos acusados um leque de direitos fundamentais relacionados ao 'julgamento justo' $e$ 'razoável', com padrões de comportamentos obrigatórios ou exigiveis do Estado, no trato dessas relações que afetam direitos fundamentais. Essa funcionalidade se coaduna com a articulação organizada, coerente e dinâmica das demais normas constitucionais que contemplam direitos fundamentais aos acusados em geral "
\end{abstract}

Intimamente ligado ao princípio do devido processo legal em sua manifestação substancial está o princípio da razoabilidade, sendo para Medina Osório impossível compreender o devido processo sem a razoabilidade. Veja-se a explicação abaixo:

"O devido processo legal não é, portanto, o respeito às leis processuais ou o produto de uma visão lógico-gramatical da legislação. Essa noção de devido processo legal é bastante ampla e não se esgota na obediência à lei em sentido formal ou literal, insista-se nesse ponto. Exige-se atendimento a um devido processo legal proporcional e razoável, sendo necessária a busca dos valores imanentes à cláusula

${ }^{152}$ OSÓRIO, Fábio Medina. Op. Cit. p. 179.

${ }^{153}$ Ibid. p. 190. 
em comento. Imperiosa a obediência aos comandos constitucionais e esses não merecem uma leitura meramente literal ${ }^{, 154}$.

Assim, para o autor, o princípio da razoabilidade é um "critério de apreciação da arbitrariedade legislativa, jurisdicional e administrativa" e uma decisão condenatória desarrazoada, por ser viciada em suas origens, é nula de pleno direito ${ }^{155}$.

Para Heraldo Garcia Vitta, razoabilidade significa o administrador valorar os fatos segundo concepções da sociedade e não mediante ideologias próprias, pessoais ${ }^{156}$.

Outro princípio decorrente do devido processo legal é o da proporcionalidade, "pilar fundamental de desenvolvimento e concretização das normas do Direito Administrativo Sancionador" ${ }^{157}$, bem como de todo e qualquer ramo do Direito, já que o princípio é intrínseco à aplicação das normas jurídicas. A proporcionalidade significa a correlação entre meios e fins, isto é, que o administrador utilize apenas os meios estritamente necessários para atender à finalidade que se pretende, sempre tendo em vista o interesse público a ser atendido ${ }^{158}$.

Contudo, a proporcionalidade não corresponde apenas a uma necessária moderação das penas estatais e dos tipos sancionadores, até porque, como destaca Fábio Medina Osório, “ao Judiciário não será lícito examinar, à luz desse princípio, se a alternativa eleita pelo legislador era a menos gravosa possível" ${ }^{159}$. A função do Judiciário é corrigir eventuais abusos, isto é, quando são eleitas alternativas ilícitas ou excessivamente gravosas. Para Fábio Medina Osório, o princípio da proporcionalidade deve levar em conta os interesses sociais "na construção dos tipos sancionadores e na concreção da resposta estatal aos fatos ilícitos praticados pelos agentes" ${ }^{160}$. Para o autor,

\footnotetext{
154 Ibid. p. 192.

155 Ibid. p. 197.

${ }^{156}$ VITTA, Heraldo Garcia. A sanção no direito administrativo. São Paulo: Malheiros, 2003. p. 97.

157 OSÓRIO, Fábio Medina. p. 197.

${ }^{158}$ Ibid. p. 197.

${ }^{159}$ Ibid. p. 198.

${ }^{160}$ Ibid. p. 198.
} 
os caminhos da proporcionalidade devem gerar o equilíbrio entre a proteção dos direitos individuais atingidos pelo processo administrativo e os direitos da comunidade protegidos mesmo pelo legislador que visa garantir os direitos individuais ${ }^{161}$.

Ademais, como todo o poder emana do povo, todos os servidores públicos servem à sociedade, atuando em nome de todo o Estado, e devem, por isso, expor as razões de fato e de direito que motivam suas decisões. Dessa forma, atenderão ao princípio da motivação, outro princípio intimamente ligado ao devido processo legal. Explicitar a motivação da decisão significa expor os fatos que originaram a ação do Poder Público, a adequação entre os fatos e o conteúdo do ato administrativo e a regra de direito em que se apoiou para proferir a decisão.

Igualmente relevante para o devido processo legal é a garantia da publicidade dos atos processuais, impedindo que haja atividade administrativa secreta. $\mathrm{O}$ art. 37 da Constituição Federal prevê que a Administração Pública direta e indireta devem obedecer ao princípio da publicidade.

\section{b. Legalidade e Tipicidade}

O poder sancionador, na medida em que integra o poder punitivo do Estado, está subordinado ao princípio da legalidade, o que significa que a lei, elaborada e aprovada por representantes do povo, confere legitimidade ao Estado para agir, ao mesmo tempo em que limita sua atuação. Vê-se que há uma vinculação positiva do Estado, isto é, sem que a lei autorize expressamente a ação do Poder Público, presume-se que o legislador não deseja que a Administração atue.

O princípio da legalidade está previsto na Constituição no art. $5^{\circ}$, inciso III ao afirmar que "ninguém será obrigado a fazer ou deixar de fazer alguma

${ }^{161}$ Ibid. p. 198. 
coisa senão em virtude de lei”, bem como no art. 37, caput, que prevê que a Administração Pública obedecerá ao princípio da legalidade.

O poder sancionador da CVM, por incidir sobre a conduta dos particulares no mercado de capitais, como não poderia deixar de ser, se submete ao princípio da legalidade. Como visto anteriormente, o art. 11 da Lei $n^{\circ}$ 6.385/1976 confere competência à autarquia para aplicar sanções não só aos infratores da própria Lei ${ }^{\circ}$ 6.385/1976 e da Lei $n^{\circ}$ 6.404/1976 como também àqueles que infringem suas resoluções e outras normas legais cujo cumprimento lhe caiba fiscalizar.

Como consequência do princípio da legalidade, decorre o princípio da tipicidade, isto é, a exigência que a lei formal defina a conduta que considera ilícita. Assim como ocorre no direito penal, "também no contexto do direito administrativo sancionador é necessário, além da lex praevia (princípio da legalidade ou reserva legal), também a lex certa (princípio da tipicidade), de vez que para que alguém possa ser punido é indispensável que tenha o prévio conhecimento da proibição da prática de determinada conduta" ${ }^{162}$.

O princípio da tipicidade exige que a conduta proibida esteja prevista na lei de forma clara, precisa e exaustiva, bem como deve ocorrer com a descrição da sanção correspondente, a fim de evitar que os regulados sejam surpreendidos - tanto pela prática de um comportamento sobre o qual não tinham conhecimento de sua ilicitude, quanto pela aplicação de sanção que também desconhecia ${ }^{163}$.

Destaca-se que, devido a esse princípio, não é possível a utilização de interpretação analógica de normas legais ou regulamentares que sejam prejudiciais ao acusado, ao passo que, por outro lado a analogia pode ser utilizada quando beneficia o acusado ${ }^{164}$.

Cumpre destacar que existem em nosso ordenamento atos normativos secundários, que são aqueles que não criam novos direitos e obrigações na

${ }^{162}$ EIZIRIK, Nelson; GAAL, Ariádina; Parente, Flávia; DE FREITAS HENRIQUES, Marcus. Op. Cit. p.288.

${ }^{163}$ Ibid. p. 134.

${ }^{164}$ Ibid. p. 289. 
ordem jurídica de modo primário, matéria esta reservada exclusivamente à lei. A esse respeito Rafael Munhoz de Mello ressalta:

“(...) afirmar que o regulamento administrativo não pode criar direitos $e$ obrigações de modo primário não significa que nenhuma inovação advenha do exercício da competência regulamentar. Os regulamentos inovam na ordem jurídica, mas de modo secundário, desenvolvendo preceitos legais já existentes " $" 65$.

Nesse sentido, o regulamento tem como função diminuir a discricionariedade da atuação dos agentes administrativos. O legislador, em determinados casos, entende que a Administração Pública tem mais recursos e condições de definir a atuação mais adequada do que ele próprio, sempre considerando o interesse público.

Feito esse esclarecimento, cumpre ressaltar importante discussão doutrinária nessa seara. Para alguns juristas, o princípio da legalidade (e, consequentemente, da tipicidade) só são efetivamente contemplados quando há previsão na lei formal da conduta ilícita e de sua sanção correspondente. Nas palavras de Rafael Munhoz de Mello "tanto a infração como a sanção administrativa devem ter previsão legal, segundo o princípio da legalidade"166. O autor ainda afirma que "a lei deve estabelecer a relação entre as infrações e as sanções administrativas, de modo que o infrator saiba exatamente a medida a que está sujeito pela prática do comportamento ilícito" 167.

Especificamente com relação à CVM, o autor afirma que, no que se refere à previsão do $\$ 3^{\circ}$ do art. 11 da Lei ${ }^{\circ}$ 6.385/1976, que dispõe que as penalidades previstas nos incisos III a VIII do caput do artigo "serão aplicadas nos casos de infração grave, assim definidas em normas regulamentares da CVM", "o princípio da legalidade é ignorado por completo"168, já que a tipificação do ilícito é feita por norma infralegal, “o

\footnotetext{
${ }^{165}$ MUNHOZ DE MELLO, Rafael. Op. Cit. p. 117.

${ }^{166}$ Ibid. p. 122.

${ }^{167}$ Ibid. p. 122.

${ }^{168}$ Ibid. p. 125.
} 
que é vedado pelo princípio da legalidade”. Assim, para o autor, o $\S 3^{\circ}$ do art. 11 da Lei ${ }^{\circ}$ 6.385/1976 seria inconstitucional.

Já Nelson Eizirik, Ariádna Gaal, Flávia Parente e Marcus de Freitas Henriques entendem que "na esfera do direito administrativo sancionador, o princípio da reserva legal vem sendo entendido de maneira mais flexível, podendo a previsão da conduta ilícita estar contida não só em lei, mas também em norma elaborada pela Administração"169.

Nesse mesmo sentido, Fábio Medina Osório afirma:

"Com efeito, os tipos do Direito Administrativo Sancionador são, em regra, mais elásticos que os tipos penais, dada a utilização da dinâmica própria do terreno administrativo e permanente inspiração dos interesses públicos e gerais a orientar feitura e aplicação das normas. As leis administrativas mudam com grande rapidez, tendem a proteger bens jurídicos mais expostos à velocidade dos acontecimentos $e$ transformações sociais, econômicas, culturais, de modo que o Direito Administrativo Sancionador acompanha essa realidade e é, por natureza, mais dinâmico que o Direito Penal (...) ${ }^{, 170}$.

Para o autor, isso ocorre devido à um abandono histórico do Direito Administrativo Sancionador, o que fez com que as normas relacionadas a ele fossem manejadas e tratadas no bojo do poder de polícia do Estado, "cujas principais características remetiam, e ainda remetem, à discricionariedade das autoridades competentes" ${ }^{171}$. Daí decorre, para Medina Osório, a flexibilidade da legalidade do Poder Administrativo Sancionador.

O que se conclui a esse respeito é que o princípio da legalidade prevê que deve haver previsão legal autorizando que determinado ente da administração pública possa sancionar os particulares. No que se refere à necessidade de previsão legal do tipo (princípio da tipicidade), há discussão na doutrina quanto a necessidade de estar disposto também em lei ou se os regulamentos administrativos estão autorizados a prevê-lo. Nesse âmbito, alinho-me com os autores que entendem ser constitucional a própria lei autorizar que regulamentos administrativos estabeleçam a conduta típica.

${ }^{169}$ EIZIRIK, Nelson; GAAL, Ariádina; Parente, Flávia; DE FREITAS HENRIQUES, Marcus. Op. Cit. p. 284.

${ }^{170}$ OSÓRIO, Fábio Medina. Op. Cit. p. 227.

${ }^{171}$ Ibid. p. 227. 
Outra questão relevante sobre o princípio da tipicidade é a que se refere sobre a crescente utilização pelo direito administrativo sancionador das normas penais em branco e dos standards jurídicos.

A norma penal em branco é aquela que contém a previsão de sanção, mas que necessita de outra norma para complementar seu conteúdo (podendo esta segunda norma ser uma lei proferida pela mesma fonte, ou baixada por outra instância legislativa). No caso do direito administrativo sancionador, admite-se que a norma penal em branco seja preenchida pela Administração Pública (no caso da CVM, por meio de normas previstas em Instruções editadas pela autarquia).

No que se refere aos standards, a jurisprudência e a doutrina têm discutido a possibilidade de serem aplicadas sanções administrativas a condutas que os firam. Standards são "conceitos amplos, não precisamente determinados e adaptáveis às circunstâncias, mediante os quais são estabelecidos os padrões legais de conduta" ${ }^{172}$. O elevado grau de abstração dos standards é considerado por alguns como uma infração ao princípio da tipicidade. Além disso, tais críticos afirmam que a utilização de standards nas sanções administrativas gera elevada discricionariedade para a atuação da Administração Pública.

Entretanto, para Eizirik, Ariádna Gaal, Flávia Parente e Marcus de Freitas Henriques, especificamente no que se refere ao mercado de capitais, "como o standard advém de conceitos que os destinatários das normas administradores de companhias abertas, instituições financeiras, etc. podem retirar de sua experiência profissional concreta, deve ser admitido o seu uso na aplicação de sanções administrativas por parte da CVM"173. É o que pensa também Rafael Munhoz de Mello, que afirma que é preciso que "o conceito jurídico indeterminado seja passível de compreensão com base em critérios lógicos, técnicos e de experiência" $"$.

\footnotetext{
${ }^{172}$ EIZIRIK, Nelson; GAAL, Ariádina; Parente, Flávia; DE FREITAS HENRIQUES, Marcus. Op. Cit. p. 291.

${ }^{173}$ Ibid. p. 291.

${ }^{174}$ MUNHOZ DE MELLO, Rafael. Op. Cit. p. 142.
} 
Ademais, seria impossível prever todas as condutas nocivas ao mercado de capitais. Sobre o tema, os 4 autores supracitados concluem:

\begin{abstract}
"Na prática, a utilização de um standard na lei importa na concessão de ampla discricionariedade à autoridade administrativa, bastante comum na esfera do direito econômico, para que ela possa preencher os vazios do padrão genérico de conduta, caso a caso, no julgamento de processos sancionadores. Mediante a aplicação de penalidades administrativas, o órgão regulador da atividade econômica sinaliza para o mercado qual a interpretação que ele está conferindo a determinado padrão de conduta", ${ }^{175}$.
\end{abstract}

Apresentando visão um pouco mais restrita, Heraldo Garcia Vitta entende que "será possível a utilização de conceitos jurídicos indeterminados ou cláusulas gerais apenas quando houver a impossibilidade de o legislador prever todos os comportamentos que possam ser sancionados"176.

\title{
c. Irretroatividade
}

O princípio da irretroatividade exige que o direito aplicável seja aquele previsto nas normas existentes à época em que a conduta foi praticada. Tal princípio decorre do princípio da segurança jurídica, tendo em vista que os particulares pautam seus comportamentos de acordo com as regras jurídicas vigentes e, não podem ser surpreendidos com alteração de lei posterior que torne o ato que cometeram ilícito ou que agrave sanção que lhes foi imposta. O princípio veda atuação arbitrária do Estado e está previsto no art. $5^{\circ}$, inciso XL da Constituição da República ${ }^{177}$.

Com relação ao princípio penal da retroatividade da lei mais benéfica, a grande maioria da doutrina entende que é aplicável ao direito sancionador. Conforme destaca Rafael Munhoz de Mello, essa é a opinião de Régis

175 EIZIRIK, Nelson; GAAL, Ariádina; Parente, Flávia; DE FREITAS HENRIQUES, Marcus. Op. Cit. p. 293.

176 VITTA, Heraldo Garcia. Op. Cit. p. 93.

177 Art. $5^{\circ}$. Todos são iguais perante a lei, sem distinção de qualquer natureza, garantindo-se aos brasileiros e aos estrangeiros residentes no País a inviolabilidade do direito à vida, à liberdade, à igualdade, à segurança e à propriedade, nos termos seguintes: XL - a lei penal não retroagirá, salvo para beneficiar o réu; 
Fernandes de Oliveira, Daniel Ferreira, Heraldo Garcia Vitta, Edilson Pereira Nobre Jr., Sérgio Ferraz e Adilson Abreu Dallari.

Entretanto, o próprio Munhoz de Mello se alinha com o entendimento de Fábio Medina Osório que defende que, no que se refere ao princípio da retroatividade da lei mais benéfica "o direito administrativo sancionador não se equipara ao direito criminal, dado seu maior dinamismo"178. Munhoz de Mello acrescenta que "a retroatividade da lei penal mais benéfica tem por fundamento razões humanitárias, relacionadas diretamente à liberdade do criminoso, bem jurídico diretamente atingido pela pena criminal" ${ }^{179}$. No direito administrativo sancionador, ressalta Munhoz, o argumento não é válido visto que a sanção administrativa não pode consistir em prisão.

Alexandre Pinheiro dos Santos, Julya Wellisch e Fábio Medina Osório recordam, ainda, que nem mesmo no direito penal a retroatividade da lei mais benéfica alcança hipóteses reguladas por normas sancionadoras em branco, "em que as normas completivas têm natureza essencialmente dinâmica e transitória" ${ }^{180}$. Assim, entendem os autores:

"Não há, portanto, segundo pensamos, automática aplicação do princípio da retroatividade da lei mais benéfica a processos administrativos sancionadores, especialmente no âmbito do mercado de capitais, que lida com normas de conduta erigidas para o tratamento de determinadas situações e de acordo com as circunstâncias de tempo e de realidade econômica subjacentes, as quais justificam sua incidência e aplicabilidade em relação a todos os atos praticados sob aquelas condições, ainda que, no futuro, a norma seja alterada para a supressão de tal ou qual ilícito específico" 181 .

\section{d. Culpabilidade}

A aplicação da sanção administrativa pressupõe uma conduta tipificada instrumentalizada por um sujeito passivo. Da culpabilidade decorre a exigência do elemento subjetivo da conduta, isto é, do dolo ou da culpa stricto sensu.

\footnotetext{
${ }^{178}$ OSÓRIO, Fábio Medina. Op. Cit. p. 289.

${ }^{179}$ MUNHOZ DE MELLO, Rafael. Op. Cit. p. 154.

${ }^{180}$ DOS SANTOS, Alexandre Pinheiro; OSÓRIO, Fábio Medina; WELLISCH, Julya Sotto Mayor. Op. Cit. pp. 55-56.

${ }^{181}$ Ibid. pp. 55-56.
} 
Conjuntamente com esse princípio, observe-se o art. $5^{\circ}$, XLV da Constituição, segundo o qual "nenhuma pena passará da pessoa do condenado". Como se vê, o ordenamento jurídico brasileiro repele a responsabilidade por fato de outrem, e, pelo princípio da culpabilidade, as sanções só podem ser impostas exclusivamente àquele que pratica a conduta típica.

Pelo que se expôs, percebe-se que existem duas decorrências do princípio da culpabilidade: (i) exigência de dolo ou culpa e (ii) vedação da responsabilidade pelo fato de outrem.

No que se refere ao primeiro ponto, é necessário que haja dolo ou culpa stricto sensu para que a Administração Pública imponha medida sancionadora. Nas palavras de Rafael Munhoz, “agir com 'dolo’ significa praticar com consciência e voluntariedade a conduta típica" ou seja, "o indivíduo deseja praticar a conduta descrita na lei formal como infração administrativa" 182 . Já na culpa stricto sensu, o agente pratica a conduta típica por falta de diligência (negligência, imperícia ou imprudência), mas não intencionalmente. Vê-se que no direito administrativo sancionador, a mera atuação culposa pode ser punida, ao passo que no direito penal, a regra para punição é da atuação dolosa.

Ressalta-se que a sanção, como um elemento punitivo do comportamento humano, só pode ser aplicada a comportamentos evitáveis, não cabendo, portanto, apenação do indivíduo quando não se pode exigir conduta diversa.

Ainda, vale salientar que apesar do desconhecimento da lei ser inescusável no nosso ordenamento, é plenamente admitida a escusabilidade do desconhecimento do injusto, conforme expressamente autorizado pelo Código Penal.

Nesse sentido, veja-se a lição de Eizirik, Ariadna Gaal, Flávia Parente e Marcus Henriques:

\footnotetext{
${ }^{182}$ MUNHOZ DE MELLO, Rafael. Op. Cit. p. 184.
} 
"No âmbito do direito administrativo sancionador do mercado de capitais, é plenamente aplicável o princípio da culpabilidade. Ou seja, não pode o agente ser punido, administrativamente, se não tiver a consciência da ilicitude de seu ato; não caracterizada a culpa ou o dolo do acusado em processo administrativo, não pode a autoridade aplicar-lhe qualquer penalidade,"183.

Com relação ao segundo ponto decorrente do princípio da culpabilidade, tem-se que as sanções administrativas só poderão ser aplicadas se comprovada a culpabilidade do agente, isto é, que este praticou com consciência, liberdade e voluntariedade um ato de caráter legalmente reprovável. Como já se afirmou, por força do inciso XLV do art. $5^{\circ}$ da Constituição, a penalidade não poderá ultrapassar a pessoa do condenado e, embora os sucessores possam ser civilmente responsabilizados em certas situações previstas na lei, não podem ser punidos administrativamente por ilícito que o sucedido cometeu.

A jurisprudência da CVM é clara nesse sentido, como se vê a seguir:

\begin{abstract}
"Os inquéritos administrativos dessa CVM visam a apuração da responsabilidade disciplinar (ou administrativa) dos indiciados. A aplicação de penalidades (...) pressupõem a culpa própria concreta e individual de cada um dos indiciados, devendo, portanto, ser analisada a sua participação efetiva nos eventos tidos ilegais. Vigora, em matéria de responsabilidade disciplinar, o princípio da culpa concreta, oposta, portanto, ao da culpa comunicável ou solidária" (IA CVM 20/88, j. 17.10.1989)

"No meu entender, uma vez que, em um caso determinado, a infração ao descrito no referido artigo [art. 163, $3^{\circ}$ da Lei no 6.404/1976] esteja caracterizada, envolvendo culpa própria, concreta e individual do indiciado, cabe aplicação de penalidade pela CVM; pois, à luz dos artigos 11 e 4", III, alínea "c", da Lei $n^{o}$ 6.385/76, dispositivos já citados pelo próprio Senhor Diretor Relator, a Autarquia pode impor penalidades aos infratores da Lei das Sociedades por Ações a fim de proteger os titulares de valores mobiliários e os investidores do mercado contra atos ilegais de administradores e acionistas 10/12 controladores das companhias abertas" (voto do diretor Eli Loria no âmbito do PAS CVM 23/05 j. 22.10.2007).
\end{abstract}

Assim, explicam os autores supracitados que "como a aplicação de penalidades por parte da CVM pressupõe a caracterização da culpa própria, concreta e individual de cada um dos indiciados, mesmo quando

${ }^{183}$ EIZIRIK, Nelson; GAAL, Ariádina; Parente, Flávia; DE FREITAS HENRIQUES, Marcus. Op. Cit. p. 295. 
componentes de órgão colegiado, deve ser exaustivamente analisada e provada a participação de cada um deles no ato tido como ilegal".

No caso da culpa in vigilando, esta é admitida no direito sancionador mas, para aplicação da sanção é fundamental provar a culpabilidade do acusado, isto é, que este, sabendo ou dispondo dos meios para saber que seu subordinado estava praticando ato ilícito, omitiu-se.

\section{e. Proibição da dupla apenação (non bis in idem)}

O princípio da proibição da dupla apenação (non bis in idem) não está previsto expressamente na Constituição, mas está constitucionalmente conectado aos princípios da legalidade, proporcionalidade e, fundamentalmente, ao devido processo legal ${ }^{184}$. O princípio do non bis in idem visa garantir que, tratando-se dos mesmos sujeitos, fatos e fundamentos, o Estado não possa aplicar ao agente sanções punitivas diversas. A ideia básica do princípio, de que ninguém pode ser condenado ou processado duas ou mais vezes por um mesmo fato, é uma concepção praticamente universal, presente, inclusive, no Pacto de San José da Costa Rica ${ }^{185}$.

Uma análise mais profunda desse princípio, no entanto, requer sua subdivisão nos dois planos em que pode ser aplicado, quais sejam, quando há sanções administrativas e penais com a referida identidade tríplice, ou quando são diversas as sanções administrativas proferidas pela Administração Pública.

No que se refere às sanções penais e administrativas e a independência entre as instâncias administrativa, penal e civil, para a doutrina clássica não há dúvidas de que, devido à separação de poderes, há independência entre essas instâncias. Heraldo Garcia Vitta destaca que embora cada uma das

\footnotetext{
${ }^{184}$ OSÓRIO, Fábio Medina. Op. Cit. p. 293.

${ }^{185}$ Artigo $8^{\circ}$ - Garantias judiciais. 4 . O acusado absolvido por sentença transitada em julgado não poderá ser submetido a novo processo pelos mesmos fatos.
} 
instâncias possa atuar independentemente da outra, o legislador pode regular o intercâmbio entre ambas ${ }^{186}$.

Contudo, Fábio Medina Osório destaca que vem ganhando corpo no direito brasileiro doutrina que mitiga e relativiza a independência entre as instâncias e discorre sobre os motivos que levaram à criação dessa doutrina, destacando a busca pelos postulados da segurança jurídica e da racionalidade estatal. Nesse sentido, afirma:

"Teoricamente, não pode o sujeito ter sua conduta considerada lícita, correta, conforme o Direito, na esfera administrativa, em determinados domínios especializados e idôneos e, ao mesmo tempo, ver-se acusado da prática de crimes em razão de supostas transgressões às mesmas normas que noutro terreno se diz que foram cumpridas integralmente. $O$ ideário de segurança e coerência, coibindo atuações abusivas ou obscuras do Estado, repercute na formação de barreiras à independência das instâncias, neste aspecto" "187.

Seguindo esse entendimento, o autor escreveu, em conjunto com Alexandre Pinheiro dos Santos e Julya Wellisch, que a independência das instâncias estatais "não pode justificar automática dupla punição de jurisdicionado ou administrado, com quebra de proporcionalidade, ou um conjunto de soluções contraditórias" ${ }^{188}$, pois, para os autores, tais resultados afrontariam o princípio da razoabilidade e da proporcionalidade e a boa-fé objetiva, que se exige permanentemente do Estado.

Entretanto, tal corrente é minoritária e ainda se põe em desenvolvimento. Sintetizando sua visão do panorama atual do direito brasileiro nesse aspecto, Medina Osório afirma:

\footnotetext{
"O sistema vigente valoriza, como vem fazendo, o princípio da independência das instâncias, numa perspectiva de separação de Poderes, em busca de um incremento das atuações estatais na proteção dos bens jurídicos ligados não apenas à probidade, mas a outros valores, dentro ou fora das relações de especial sujeição. A visão consolidada majoritariamente é restritiva, estimulando que um sujeito, por um mesmo fato, responda algumas possíveis intervenções punitivas provenientes de instâncias diversas (...). Estas sanções podem ser repetidas, dando lugar a que se

186 VITTA, Heraldo Garcia. Op. Cit. p. 117.

187 OSÓRIO, Fábio Medina. Op. Cit. p. 297.

${ }^{188}$ DOS SANTOS, Alexandre Pinheiro; OSÓRIO, Fábio Medina; WELLISCH, Julya Sotto Mayor. Op. Cit. p. 66.
} 
discuta sobre os limites dessa repetição e da quantificação final das penas. Podem, no entanto, tais sanções, apresentarem-se de modo original, complementando-se. (...) O máximo a que se tem chegado, dentro desse entendimento, é a redução de patamares de apenamento, seja pecuniário, seja em termos de prazos para suspensão ou restrição de direitos. (...) Por aí tem transitado tanto a ideia de proporcionalidade quanto, em maior medida, uma hermenêutica restrita e limitada em torno ao princípio do non bis in idem na jurisprudência e doutrina brasileiras, ainda predominando o ideário ínsito à independência das instâncias, como corolário da separação de poderes, em detrimento de outras alternativas igualmente legítimas. E vale destacar que a radicalização dessa independência das instâncias tem conduzido, não raro, ao isolacionismo das instâncias, à falta de harmonia entre os Poderes e à insegurança jurídica, em muitos níveis relevantes" $"$ "189.

No âmbito do direito administrativo sancionador, o princípio se traduz na proibição da Administração Pública aplicar uma segunda sanção administrativa a quem já sofreu, pela mesma conduta sobre os mesmos fatos, uma primeira sanção administrativa.

Há que se observar que com o desenvolvimento estatal, muitas vezes há mais de um órgão perseguindo e analisando os mesmos fatos, embora sob a justificativa de tutelarem bens jurídicos diferentes. A teoria do bem jurídico, tendo em vista seu alto grau de abstração, vem justificando atuações de órgãos distintos e, por vezes, subjetivas ${ }^{190}$. Se existem diversos reguladores fiscalizando e tutelando o mesmo bem jurídico ou resguardando valores eventualmente análogos, é recomendável que haja uma cooperação institucional entre os entes estatais. Nesse sentido, afirmam Alexandre Pinheiro dos Santos, Fábio Medina Osório e Julya Wellisch:

\begin{abstract}
"Se um mesmo fato é apurado por distintos órgãos ou entidades, é legitimo presumir que estes, em algum grau, atuam em conjunto, comunicando-se entre si e entabulando estratégias coordenadas para, em regime de consenso, alcançarem todos os resultados de interesse comum. $\underline{O}$ que não resulta aceitável é debitar ao jurisdicionado ou administrado eventual falha de comunicação ou desorganização estatal $^{, 191}$.
\end{abstract}

No mesmo sentido, Rafael Munhoz de Mello afirma:

\footnotetext{
189 OSÓRIO, Fábio Medina. Op. Cit. pp. 301-302.

190 Ibid. pp. 294-300.

${ }^{191}$ DOS SANTOS, Alexandre Pinheiro; OSÓRIO, Fábio Medina; WELLISCH, Julya Sotto Mayor. Op. Cit. p. 66.
} 
"Não se pode admitir, em casos tais lem que há mais de uma autoridade competente para aplicação da mesma sanção administratival, que todos os órgãos competentes apliquem de modo cumulativo a sanção administrativa prevista na lei. O legislador, ao tipificar a conduta delituosa, estabeleceu a sanção administrativa adequada e proporcional ao fato praticado e à finalidade preventiva que justifica o exercício da competência punitiva pela Administração. A sanção adequada e proporcional prevista em lei pressupõe uma única aplicação para cada conduta delituosa, não diversas ${ }^{, 192}$.

\section{f. Presunção da inocência}

O princípio da presunção da inocência é garantido pelo art. $5^{\circ}$, LVII da Constituição nos seguintes termos: "ninguém será considerado culpado até o trânsito em julgado da sentença penal condenatória”. Apesar do texto constitucional referir-se à sentença penal, o princípio também é aplicável ao direito administrativo sancionador, por força do princípio da máxima efetividade das garantias constitucionais ${ }^{193}$, tendo a CVM já se manifestado diversas vezes que o princípio é plenamente aplicável ${ }^{194}$.

A presunção de inocência garante que o acusado somente sofra a apenação estatal após decisão final da autoridade competente. Até esse momento, sobrevive a dúvida a respeito das ações ou do sujeito do acusado, que é a base do processo. Sendo assim, a dúvida deve favorecer aos acusados, cabendo ao Estado "provar os fatos constitutivos do ius puniendi, ainda que mediante legítima utilização de prova indiciária" ${ }^{195}$. Nesse sentido ${ }^{196}$, a ex Diretora da CVM Norma Parente afirmou em seu voto no âmbito do PAS CVM nº RJ 06/1995, julgado em 05.05.2005:

\footnotetext{
${ }^{192}$ MUNHOZ DE MELLO, Rafael. Op. Cit. p. 211.

193 Idem, p. 245.

${ }^{194}$ Veja-se os processos CVM n. RJ2001/0134, Rel. Dir. Luiz Antonio de Sampaio Campos, j. 30.08.2002, CVM No SP2014/0465, Rel. Dir. Gustavo Machado Gonzalez, j. 06.11.2018.

195 DOS SANTOS, Alexandre Pinheiro; OSÓRIO, Fábio Medina; WELLISCH, Julya Sotto Mayor. Op. Cit. p. 77.

${ }^{196}$ No mesmo sentido, o ex Diretor da CVM Luiz Antônio Sampaio Campos: “As perplexidades $e$ dificuldades que envolvem a aceitação de indícios como elementos suficientes a amparar uma condenação estão centradas no juízo de certeza que se exige para condenar e no princípio in dubio pro reo. Portanto, todo o esforço da doutrina e da jurisprudência que aceitam a condenação com base em indícios dirigiu-se para cercar a utilização de indícios da necessária segurança, como forma de conciliá-lo com o juízo de certeza e a presunção de inocência; e de se acautelar contra certos voluntarismos e evitar desvios de raciocínio." (Voto no PAS CVM n ${ }^{\circ}$ RJ2002/2405, julgado em 09.10.2003)
} 
"Os indícios possuem valor probatório suficiente para ensejar condenação. Exigese, todavia, que tais indícios sejam convergentes e unívocos. A existência de contraindícios suficientes para inspirar dúvida nos julgadores deve conduzir à absolvição, em homenagem ao princípio da presunção de inocência".

Como se vê, a presunção da inocência não é absoluta e deve ser considerada a partir do ônus probatório, em cada caso concreto, à luz do princípio da razoabilidade ${ }^{197}$. Cabe à Administração comprovar a ocorrência dos fatos e a autoria (o binômio autoria e materialidade, definido como "justa causa"198) e, "se o indiciado alegar a existência de causas excludentes da ilicitude, da tipicidade, da antijuridicidade, ou extintiva da punibilidade, é seu o ônus da prova, à semelhança da orientação fixada no âmbito do processo penal" 199 .

\section{IV.4. A Lei da Liberdade Econômica}

Expostos os princípios constitucionais do direito punitivo que devem ser observados pela CVM, cabe fazer uma ressalva quanto a Lei $n^{\circ}$ 13.874/2019, que regulamenta o fundamento constitucional da livre iniciativa $^{200}$. Em setembro deste ano, a medida provisória $\mathrm{n}^{\circ} 881$, conhecida como "MP da liberdade econômica" foi convertida na referida lei, instituindo a "declaração de direitos de liberdade econômica" no Brasil e estabelecendo garantias que visam assegurar o livre mercado e a livre iniciativa no país.

A Lei $n^{0}$ 13.874/2019 não configura um limite objetivo à atuação sancionadora da CVM, mas prevê princípios que a autarquia deve observar

\footnotetext{
${ }^{197}$ DOS SANTOS, Alexandre Pinheiro; OSÓRIO, Fábio Medina; WELLISCH, Julya Sotto Mayor. p. 77.

${ }^{198}$ A justa causa é exigida, inclusive, para a formulação da acusação. Especificamente com relação à materialidade, o fato deve ser provado desde a peça acusatória, não devendo ser admitida acusação baseada em suposições da ocorrência do fato típico. A única hipótese permitida é com relação à autoria, ou seja, "constatado o ilícito, a lei admite que alguém seja tido como seu provável autor, com base em circunstância de fato que levem razoavelmente a essa presunção”. EIZIRIK, Nelson; GAAL, Ariádna; Parente, Flávia; DE FREITAS HENRIQUES, Marcus. Op. Cit. p. 302.

199 Idem, p. 301.

${ }^{200}$ Art. $1^{\text {o }}$ A República Federativa do Brasil, formada pela união indissolúvel dos Estados e Municípios e do Distrito Federal, constitui-se em Estado Democrático de Direito e tem como fundamentos: (...) IV - os valores sociais do trabalho e da livre iniciativa.
} 
quando da aplicação de seu poder sancionador. Isto é, a Lei ${ }^{\circ}$ 13.874/2019 não reprime o poder sancionador em si, mas estabelece diretrizes que devem guiar sua aplicação pela autarquia.

O cerne das disposições previstas na Lei encontra-se no seu $\operatorname{art} .1^{\circ}, \S 2^{\circ}$, que prevê que todas as normas de ordenação pública sobre atividades econômicas privadas devem ser interpretadas 201 "em favor da liberdade econômica, da boa-fé e do respeito aos contratos, aos investimentos e à propriedade". São princípios que norteiam a referida lei:

"I - a liberdade como uma garantia no exercício de atividades econômicas;

II - a boa-fé do particular perante o poder público;

III - a intervenção subsidiária e excepcional do Estado sobre o exercício de atividades econômicas; $e$

$I V$ - o reconhecimento da vulnerabilidade do particular perante o Estado ${ }^{202}$

Assim, tais princípios devem nortear o poder sancionador da CVM, que não pode ignorá-los. Veja-se que o Código de Processo Civil de 2015 prevê a obrigatoriedade de fundamentação das sentenças pelos magistrados ${ }^{203}$, bem como dispõe que a modificação de jurisprudência pacificada deverá considerar os princípios da segurança jurídica, da proteção da confiança e da isonomia ${ }^{204}$.

\footnotetext{
201 Art. $1^{\mathrm{o}}, \S 1^{\mathrm{o}}$. Interpretam-se em favor da liberdade econômica, da boa-fé e do respeito aos contratos, aos investimentos e à propriedade todas as normas de ordenação pública sobre atividades econômicas privadas.

${ }^{202}$ Art. $2^{\circ}$ da Lei $n^{\circ} 13.874 / 2019$.

${ }^{203}$ Art. 489. São elementos essenciais da sentença: (...)II - os fundamentos, em que o juiz analisará as questões de fato e de direito; III - o dispositivo, em que o juiz resolverá as questões principais que as partes lhe submeterem.

$\S 1^{\circ}$ Não se considera fundamentada qualquer decisão judicial, seja ela interlocutória, sentença ou acórdão, que: (...) V - se limitar a invocar precedente ou enunciado de súmula, sem identificar seus fundamentos determinantes nem demonstrar que o caso sob julgamento se ajusta àqueles fundamentos; VI - deixar de seguir enunciado de súmula, jurisprudência ou precedente invocado pela parte, sem demonstrar a existência de distinção no caso em julgamento ou a superação do entendimento.

${ }^{204}$ Art. 927. Os juízes e os tribunais observarão: (...) $§ 4^{\circ}$ A modificação de enunciado de súmula, de jurisprudência pacificada ou de tese adotada em julgamento de casos repetitivos observará a necessidade de fundamentação adequada e específica, considerando os princípios da segurança jurídica, da proteção da confiança e da isonomia.
} 
Nesse sentido, em linha com o disposto no CPC 2015, a CVM também deve observar os princípios a ela aplicáveis na sua atuação sancionadora. Outro não é o entendimento de Fábio Medina Osório ${ }^{205}$ :

\footnotetext{
"Entendo que tais dispositivos do Novo CPC devem servir de referência às autoridades administrativas na fundamentação de suas decisões, eis que também estão submetidas ao princípio constitucional de interdição à arbitrariedade estatal".
}

A edição da Lei no 13.874/2019 demonstra que o Brasil caminha para criar um ambiente econômico menos intervencionista, que preze pela liberdade econômica e pela livre iniciativa, e é dessa forma que a CVM deve pautar sua atuação.

\section{IV.5. Outros meios de exercício do poder regulador}

Conforme visto acima, os princípios constitucionais aplicáveis ao direito punitivo são, sem dúvida, forte barreira que impõe limites à atividade sancionadora da CVM, dado que decorrem da carta magna de nosso ordenamento jurídico. Entretanto, tais limites ultrapassam a aplicação dos princípios constitucionais, cabendo à autarquia observar outros métodos que podem substituir, quando aplicáveis, a atividade sancionadora.

Para o ex diretor presidente da autarquia Marcelo Trindade, a CVM não deve se utilizar do processo sancionador, por exemplo, para exarar pela primeira vez seu entendimento ou para pacificar controvérsias sobre normas sobre as quais ainda não tenha emitido posição definitiva. Para Trindade, nesses casos a autarquia corre o risco de aplicar entendimento novo a fatos antigos, o que configuraria inobservância ao princípio da irretroatividade. Veja-se:

“(...) a CVM pode manifestar entendimentos, iniciar fiscalizações preventivas, expedir ordens de alteração de condutas, sem utilizar-se do processo sancionador para dar à luz suas opiniões nunca antes anunciadas. Em situações como essa, a

${ }^{205}$ OSÓRIO, Fábio Medina. Op. Cit. p. 171. 
utilização do processo sancionador quase sempre envolverá o risco de a CVM aplicar retroativamente - isto é, a eventos passados - entendimentos de momento, não estabilizados, ou visões que se estabilizaram apenas posteriormente aos fatos analisados no processo"206.

Como destacado pelo professor, a autarquia possui outros meios menos aflitivos do que processo administrativo sancionador para dirimir controvérsias ou para manifestar seu entender sobre determinada matéria pela primeira vez. Nesse sentido, o art. 13 da Lei ${ }^{\circ}$ 6.385/1976 prevê que a CVM “manterá serviço para exercer atividade consultiva ou de orientação junto aos agentes do mercado de valores mobiliários ou a qualquer investidor".

Um exemplo da atividade de orientação que a CVM pode exercer é a expedição de pareceres de orientação, atos emitidos para orientar os agentes do mercado e os investidores sobre determinada matéria cuja regulamentação seja de competência da autarquia e para veicular as manifestações da autarquia acerca da interpretação das Leis $n^{\circ}$ 6.385/1976 e n 6.404/1976, sempre no interesse do mercado de capitais. Até o presente momento já foram emitidos 38 pareceres de orientação sobre diversas matérias, entre elas os deveres fiduciários dos administradores nas operações de fusão, incorporação e incorporação de ações envolvendo a sociedade controladora e suas controladas ou sociedades sob controle comum (Parecer de Orientação $\mathrm{n}^{\mathrm{o}}$ 35), ou, de forma ainda mais específica, já foram emitidos pareceres que dão interpretação sobre determinado artigo, como é o caso do Parecer de Orientação $n^{\circ} 25$, que dá a interpretação da autarquia sobre o art. 30 da Instrução CVM nº 177/1992.

Nesse mesmo sentido, cabe às áreas técnicas da CVM a emissão de ofícios circulares, ofícios cuja finalidade é orientar os regulados sobre determinados normativos.

Outra forma mais branda do que a instalação de um processo administrativo sancionador da qual a CVM pode se utilizar é a emissão das

\footnotetext{
206 TRINDADE, Marcelo. In: VENANCIO FILHO, Alberto; LOBO, Carlos Augusto da Silveira; ROSMAN, Luiz Alberto Colonna (coord). Op. Cit. p. 497.
} 
chamadas "manifestações de entendimento". Em seu voto emitido no âmbito de um recurso ao colegiado da Companhia Força e Luz CataguazesLeopoldina contra manifestação de entendimento da Superintendência de Relações com Empresas, o então diretor presidente da CVM Marcelo Trindade explicou o que são as manifestações de entendimento:

"Trata-se da manifestação, pela CVM, de seu entendimento sobre a ocorrência, ou não, de violação da lei, de regulamento ou de norma estatutária, contratual ou de auto-regulação, em relação a uma determinada operação ou conjunto de operações. Em uma palavra: através da manifestação de entendimento a CVM opina sobre a legalidade, lato senso, de um ato ou um conjunto de atos" 207 .

Veja-se que as manifestações de entendimento têm caráter diferente dos pareceres de orientação e dos ofícios circulares, na medida em que são emitidas com relação a um caso concreto, que está em vias de ocorrer ou já esteja ocorrendo. Não se trata, portanto, de uma interpretação em abstrato da norma ou do comportamento esperado dos participantes do mercado, mas sim do entendimento da CVM sobre a legalidade de uma situação de fato.

Para o ex diretor, o referido art. 13 da Lei $n^{\circ}$ 6.385/1976 também autoriza a CVM a emitir manifestações de entendimento, bem como o art. $4^{\circ}$, IV, b da mesma lei, que prevê como finalidade da CVM "proteger os titulares de valores mobiliários e os investidores do mercado contra atos ilegais de administradores e acionistas controladores das companhias abertas, ou de administradores de carteira de valores mobiliários". De forma mais específica, o diretor considera, ainda, que o art. $124, \S 5^{\circ 208}$ da Lei das S.A.

\footnotetext{
${ }^{207}$ Voto do Diretor Presidente Marcelo Trindade, no âmbito dos Processos CVM nos RJ/2004/4558, $\mathrm{RJ} / 2004 / 4559, \mathrm{RJ} / 2004 / 4569$ e RJ/2004/4583, julgados em 21.09.2004.

$208 \S 5^{\circ}$. A Comissão de Valores Mobiliários poderá, a seu exclusivo critério, mediante decisão fundamentada de seu Colegiado, a pedido de qualquer acionista, e ouvida a companhia:

I - aumentar, para até 30 (trinta) dias, a contar da data em que os documentos relativos às matérias a serem deliberadas forem colocados à disposição dos acionistas, o prazo de antecedência de publicação do primeiro anúncio de convocação da assembléia-geral de companhia aberta, quando esta tiver por objeto operações que, por sua complexidade, exijam maior prazo para que possam ser conhecidas e analisadas pelos acionistas;

II - interromper, por até 15 (quinze) dias, o curso do prazo de antecedência da convocação de assembléia-geral extraordinária de companhia aberta, a fim de conhecer e analisar as propostas a serem submetidas à assembléia e, se for o caso, informar à companhia, até o término da interrupção, as razões pelas quais entende que a deliberação proposta à assembléia viola dispositivos legais ou regulamentares.
} 
também autoriza as manifestações de entendimento. Ressalte-se que a autarquia tem discricionariedade no que se refere à edição de manifestação de entendimento, ou seja, cabe à CVM examinar a conveniência e a oportunidade de sua manifestação e de sua divulgação. E, a respeito da efetividade das manifestações, Trindade conclui em seu voto:

"Sendo assim, as manifestações de entendimento, por mais persuasivas que possam ser - seja para causar a interrupção voluntária dos atos por elas examinados (quando prévias), seja para gerar o desfazimento voluntário de tais atos (quando posteriores) -, têm apenas este poder persuasório. No caso de prática de atos, ou de manutenção de efeitos de atos, que a CVM tenha entendido ilegais por manifestação de entendimento, o remédio remanescente será a instauração de processo administrativo sancionador, para a imposição, se for o caso, e depois de observado o devido processo legal, das penalidades estabelecidas no art. 11 da Lei 6.385/76".

Vê-se, portanto, que as manifestações de entendimento não substituem os processos administrativos sancionadores caso os atos que a CVM entenda ilegais continuem a ser praticados. Entretanto, a emissão de tais manifestações pode evitar que tais processos sejam instaurados, na medida em que os agentes de determinado caso concreto têm a oportunidade de cessar (ou de não realizar) condutas ilícitas, evitando que tais participantes do mercado passem pelo penoso e custoso rito de um processo sancionador.

Cumpre dizer, também, que em 2006 foi publicada a Resolução n $^{\circ}$ 3.427 do CMN que estabeleceu que a CVM deveria adotar um modelo de organização e supervisão do mercado de valores mobiliários baseado em risco $^{209}$. Segundo o parágrafo único do art. $1^{\circ}$ da resolução, entende-se por modelo de supervisão baseado em risco (SBR) um sistema de regulação e fiscalização do mercado de valores mobiliários que:

I - identifique os riscos a que está exposto o mercado supervisionado;

II - dimensione tais riscos, classificando-os inclusive segundo níveis de dano potencial; III - estabeleça formas de mitigar os riscos identificados e dimensionados; $e$

IV - controle e monitore a ocorrência dos eventos de risco.

\footnotetext{
${ }^{209}$ Art. $1^{\circ}$ da Resolução nº 3.427 do CMN.
} 
Não por outro motivo, à época, a CVM editou a Deliberação CVM n ${ }^{\circ}$ 542, hoje revogada pela Instrução CVM n ${ }^{\circ} 607$, que dispunha sobre a adoção de procedimentos preventivos e orientadores no âmbito da atividade fiscalizadora da CVM. A ICVM n 607, por sua vez, também prevê a possibilidade de a autarquia utilizar-se de medidas de supervisão, como por exemplo de ofícios de alerta ${ }^{210}$.

Segundo a própria autarquia divulga em seus relatórios de atividade sancionadora, os ofícios de alerta têm por objetivo "comunicar irregularidades que não justificam a instauração de inquérito administrativo ou o oferecimento de termo de acusação"211. O instrumento visa notificar participante do mercado sobre algum desvio observado e, se for o caso, determinar prazo para a correção da conduta. Tal procedimento evita, portanto, a instauração de processo administrativo sancionador.

Por fim, cabe destacar também a possibilidade de celebração de termo de compromisso, instrumento previsto no $\$ 5^{\circ}$ do art. 11 da Lei $n^{\circ} 6.385 / 1976$ e no capítulo IV da Instrução CVM n o 607. Embora não seja um método que necessariamente substitua o processo administrativo sancionador, uma vez que pode ser celebrado enquanto o processo já está em curso ${ }^{212}$, (embora também possa ser celebrado antes ou durante a fase de apuração preliminar dos fatos ${ }^{213}$ ), o termo de compromisso pode ser menos aflitivo ao acusado pois encerra o processo quando de sua celebração e pode prever sanção mais branda do que a que seria aplicada no caso de condenação em um PAS

Cumpre dizer que a celebração de termo de compromisso não importa em confissão do acusado quanto à matéria de fato, nem em reconhecimento

\footnotetext{
${ }^{210}$ Art. $4^{\circ}, \S 2^{\circ}$ da ICVM 607.

${ }^{211}$ Relatório CVM sobre atividade sancionadora, $2^{\circ}$ trimestre de 2019. Disponível em http://www.cvm.gov.br/export/sites/cvm/publicacao/relatorio_atividade_sancionadora/anexos/201 9/20190905_relatorio_atividade_sacionadora_20_trimestre_2019.pdf. Acessado em novembro de 2019.

${ }^{212}$ Art. 82, $\S 1^{\circ}$ da Instrução $C V M n^{\circ} 607$. O interessado deverá manifestar sua intenção de celebrar termo de compromisso no prazo para a apresentação de defesa.

Art. 82, § $2^{\circ}$ Instrução da CVM n ${ }^{\circ}$ 607. A proposta completa de termo de compromisso deverá ser encaminhada à CCP em até 30 (trinta) dias após a apresentação de defesa.

${ }^{213}$ Art. 82, $\S 3^{\circ}$ Instrução da CVM n ${ }^{\circ}$ 607. Será admitida a apresentação de proposta de celebração de termo de compromisso ainda antes ou na fase de apuração preliminar dos fatos, que, neste caso, deverá ser encaminhada à superintendência responsável pela apuração.
} 
de ilicitude da conduta analisada ${ }^{214}$. Para celebrar o termo de compromisso, o interessado deve cessar a prática de atividades ou atos considerados ilícitos, se for o caso, e corrigir as irregularidades apontadas, inclusive indenizando os prejuízos. ${ }^{215}$ Entretanto, a CVM não está obrigada a celebrar termo de compromisso, sendo esta uma decisão discricionária da autarquia, após análise de conveniência e oportunidade para o atendimento ao interesse público $^{216}$.

Após a análise dos diversos instrumentos acima, percebe-se que a CVM tem ao seu dispor outros meios que possibilitam o cumprimento de suas funções previstas no art. $4^{\circ}$ da Lei $n^{\circ} 6.385 / 1976$ e que sejam menos aflitivos do que o processo administrativo sancionador.

É fato que o processo administrativo sancionador é um instrumento válido e eficiente para a persecução dos agentes que cometam determinados ilícitos. No entanto, conforme o art. $9^{\circ}, \S^{\circ}$ da Lei $n^{\circ} 6.385 / 1976$ e a nova Instrução CVM nº 607 disciplinam, existem casos em que a conduta ilícita é pouco relevante ou configura uma ameaça ou lesão pouco expressiva ao bem jurídico tutelado. São nesses casos, bem como nos casos em que a CVM ainda não se manifestou ou pacificou determinado tema, que é possível e, por todo o exposto, preferível ${ }^{217}$, que a autarquia utilize outros instrumentos para evitar ou cessar tais condutas ilícitas.

\footnotetext{
${ }^{214}$ Art. 81 da Instrução CVM n ${ }^{\circ} 607$.

${ }^{215}$ Art.82 da Instrução CVM no 607.

${ }^{216}$ Art. $11, \S 5^{\circ}$ da Lei $\mathrm{n}^{\circ} 6.385 / 1976$.

${ }^{217}$ Nesse sentido, Marcelo Trindade afirma: "A sanha pela punição e os holofotes que ela gera constituem permanente e perigosa tentação que o regulador deve evitar. Mas é o uso combinado dos poderes conferidos à CVM, de maneira equilibrada e com a ponderação das situações a que cada um deles melhor se adapta, que será mais eficiente para o mercado e mais justo para os regulados". TRINDADE, Marcelo. In: Lei das S.A. em seus 40 anos. VENANCIO FILHO, Alberto; LOBO, Carlos Augusto da Silveira; ROSMAN, Luiz Alberto Colonna (coord). Op. Cit. p. 499.
} 


\section{CONCLUSÃO}

A Comissão de Valores Mobiliários é o órgão atualmente responsável pela supervisão do mercado de capitais brasileiro e seus agentes. Conforme se viu ao longo deste trabalho, a CVM foi criada em 1976 pela Lei $n^{\circ} 6.385$ e teve sua natureza jurídica, bem como seus poderes modificados algumas vezes até o presente momento. Como visto, a Lei n ${ }^{\circ} 6.385$ também sofreu diversas reformas e alterações intimamente ligadas às funções da CVM.

Atualmente, a autarquia possui a dupla função de regulamentar, fiscalizar e sancionar o mercado de capitais brasileiro e seus agentes ao mesmo tempo em que cabe a ela também estimular o crescimento desse mercado.

Os poderes de regulamentação e fiscalização constituem o poder de polícia da autarquia, e decorre dele a possibilidade de a CVM aplicar ações coercitivas repressivas e imediatas para impedir ou frear o descumprimento das normas que the cabe fiscalizar. Assim, viu-se que os poderes normativo e de fiscalização são instrumentos por meio do qual o poder de polícia se concretiza.

Tal poder, contudo, não se confunde com o poder sancionador da autarquia. O poder sancionar se manifesta quando a autarquia instaura um procedimento administrativo após prévia apuração, respeitando o devido processo legal e que leve à aplicação de pena seguindo gradação prevista em lei, sendo um poder autônomo com relação ao poder de polícia. O poder sancionador, ao contrário do poder de polícia, configura um poder punitivo que tem o condão de afetar direitos fundamentais dos indivíduos e é justamente por isso que a delimitação clara dos limites que a ele se impõem é de extrema relevância.

Assim, o presente trabalho expôs os limites aos quais a CVM está submetida ao exercer o seu poder sancionador. $\mathrm{O}$ rol art. $9^{\circ}, \mathrm{V}$ da Lei de Mercado de Capitais é um limite ao poder sancionador da autarquia na medida em que prevê quais indivíduos estão sujeitos a esse poder. Devido ao princípio da legalidade e ao fato de que a atuação sancionadora tem caráter 
aflitivo, me parece que a melhor interpretação para este rol é a restritiva. Também foram apresentados os limites temporais, referentes à prescrição, aos quais a Administração Pública está sujeita, destacando-se as principais discussões acerca deste assunto. $\mathrm{O}$ fato dessas discussões ainda ocorrem 20 anos depois da edição da Lei nº 9.873/1999 gera grande insegurança jurídica aos regulados.

Ademais, a Constituição da República de 1988 prevê princípios que devem ser observados pelo Estado na aplicação de seu ius puniendi. Tais princípios constitucionais condicionam a interpretação e aplicação da regra que lhes dá concreção. Nesse sentido, a CVM deve observar os princípios do devido processo legal, da legalidade, da tipicidade, da irretroatividade, da culpabilidade, do non bis in idem e da presunção de inocência, bem como os subprincípios decorrentes destes.

Afora os limites constitucionais impostos para a instauração de um PAS, observou-se que autarquia tem à sua disposição outros meios de enforcement menos aflitivos e por vezes, mais justos, para a persecução de seus fins. Conforme a Lei $n^{\circ} 6.385 / 1976$, é preciso que a CVM pondere a relevância dos ilícitos para o mercado de capitais e o grau de lesão que tal ilícito causará ao bem jurídico tutelado. Em casos como a primeira manifestação da autarquia sobre determinado assunto ou em casos em que a CVM deseja pacificar ponto controverso em sua jurisprudência ou, ainda, quando restar comprovada a baixa expressividade do ilícito, mostra-se mais benéfico para o mercado e para seus participantes que a autarquia opte pela emissão do seu entendimento por outros meios menos aflitivos do que o processo administrativo sancionador, bem como pelo diálogo com os participantes do mercado.

O órgão regulador deve, sim, utilizar o seu poder sancionador para reprimir ilícitos e atingir suas funções precípuas. Utilizar o poder sancionador de forma ponderada coaduna-se com a dupla função atribuída a autarquia de estimular o crescimento do mercado nacional de valores mobiliários e de proteção à poupança popular. No entanto, o que me parece 
maléfico, é a utilização do poder sancionador de forma exagerada ou desnecessária. 


\section{REFERÊNCIAS BIBLIOGRÁFICAS}

BANDEIRA DE MELLO, Celso Antônio. Curso de Direito Administrativo. $28^{a}$ edição. São Paulo: Malheiros, 2011.

CANTIDIANO, Luiz Leonardo. Estudos de Direito Societário. Rio de Janeiro: Renovar, 1999, 183 p.

CAVALI, Marcelo Costernaro. Fundamento e limites da repressão penal da manipulação do mercado de capitais: uma análise a partir do bem jurídico da capacidade funcional alocativa do mercado. São Paulo. 2017. 352 p. Tese (Doutorado em Direito). Programa de Pós-Graduação em Direito da Faculdade de Direito da Universidade de São Paulo.

CHEDIAK, Julian Fonseca da Peña. A Reforma do Mercado de Valores Mobiliários. In: Reforma da Lei das Sociedades Anônimas: inovações e questões controvertidas da Lei $n^{\circ}$ 10.303, de 31.10.2001. LOBO, Jorge (coord). Rio de Janeiro: Forense, 2002.

CODORNIZ, Gabriela; PATELLA, Laura (coord). Comentários à Lei do Mercado de Capitais - Lei $n^{\circ}$ 6.385/76. São Paulo: Quartier Latin, 2015.

DOS SANTOS, Alexandre Pinheiro; OSÓRIO, Fábio Medina; WELLISCH, Julya Sotto Mayor. Mercado de Capitais: Regime Sancionador. São Paulo: Saraiva, 2012.

EIZIRIKI, Nelson. A urgente reforma da lei 6.385/76. In: Revista de Direito Mercantil. n ${ }^{\circ}$ 98. p. 58.

EIZIRIK, Nelson; GAAL, Ariádina; Parente, Flávia; DE FREITAS HENRIQUES, Marcus. Mercado de Capitais: Regime Jurídico. Rio de Janeiro: Renovar, 2008. 
EIZIRIK, Nelson. O colegiado da CVM e o CRSFN como juízes administrativos: reflexões e revisão. In: Revista dos Tribunais Online. Vol. 8. 2006. pp-273-279.

FILHO, José dos Santos Carvalho. Manual de Direito Administrativo. 31 ed. São Paulo: Atlas, 2017.

GALVÊAS, Ernane. O Mercado de Capitais Brasileiro. In: Revista de Direito Bancário e do Mercado de Capitais. vol. 41. 2008. p. 14.

GUERREIRO, José Alexandre Tavares. Sobre o Poder Disciplinar da CVM. In: Revista de Direito Mercantil, Industrial, Econômico e Financeiro. Vol 43. São Paulo: Revista dos Tribunais, 1981.

LORIA, Eli. A prescrição do exercício da ação punitiva no âmbito dos processos administrativos sancionadores da CVM. In: Revista de Direito Bancário e do Mercado de Capitais. Vol. 82/2018. pp. 53-79.

MEIRELLES, Hely Lopes; BURLE FILHO, José Emanuel. Direito Administrativo Brasileiro. 42a edição. São Paulo: Malheiros, 2016.

MUNHOZ DE MELLO, Rafael. Princípios Constitucionais do Direito Administrativo Sancionador: As Sanções Administrativas à Luz da Constituição Federal de 1988. São Paulo: Malheiros, 2007.

NERY JR, Nelson. Princípios do processo civil na Constituição Federal. São Paulo: RT, 2000.

OSÓRIO, Fábio Medina. Direito Administrativo Sancionador. $5^{\mathrm{a}}$ edição. São Paulo: Revista dos Tribunais, 2015. 
PACHECO, Aline; DE CERQUEIRA, Bruno Saraiva Pedreira; MERQUES, Evy Cynthia; e MILNITZKY, Mariana Ventura. CVM: Limites de sua competência. In: Mercado de Capitais Brasileiro II - Doutrina, Cases \& Materials. PENTEADO, Mauro Rodrigues (coord). São Paulo: Quartier Latin, 2014.

TRINDADE, Marcelo. Processo Sancionador na CVM: limites e possibilidades. In: A Lei das S.A. em seus 40 anos. VENANCIO FILHO, Alberto; LOBO, Carlos Augusto da Silveira; e ROSMAN, Luiz Alberto Colonna (coord). Rio de Janeiro: Forense, 2017. pp. 481-500.

VERÇOSA, Haroldo Malheiros Duclerc. Considerações sobre o sistema financeiro. Crises. Regulação e re-regulação. Revista de direito mercantil, industrial, econômico e financeiro. São Paulo: RT, ano XLVII, n. 149-150, jan-dez 2008.

VITTA, Heraldo Garcia. A sanção no direito administrativo. São Paulo: Malheiros, 2003.

WELLISCH, Julya Sotto Mayor. DOS SANTOS, Alexandre Pinheiro. A Evolução do Processo Administrativo Sancionador no Âmbito da Comissão de Valores Mobiliários. In: Revista de Direito Bancário e do Mercado de Capitais, vol. 48/2010. 2017. pp. 53 - 80.

WELLISCH, Julya Sotto Mayor. DOS SANTOS, Alexandre Pinheiro. Enforcement e mecanismos de solução alternativa de conflitos no mercado de capitais. In: Revista dos Tribunais Online. Vol. 53/2017. pp. 357-380.

Processo Administrativo Sancionador CVM nº RJ2001/0134, rel. dir. Luiz Antonio de Sampaio Campos, julgado em 30.08.2002. 
Processo Administrativo Sancionador CVM n⿳ RJ2002/2405, dir. relatora Norma Parente, julgado em 09.10.2003.

Processo Administrativo Sancionador CVM no 22/94, dir. relator Luiz Antônio de Sampaio Campos, julgado em 15.04.2004.

Processo Administrativo Sancionador CVM n ${ }^{\circ}$ 2002/1823, dir. relatora Norma Parente, julgado em 14.03.2005.

Processo Administrativo Sancionador CVM n ${ }^{\circ}$ RJ06/1995, dir. relatora Norma Parente, julgado em 05.05.2005.

Processo Administrativo Sancionador CVM no 23/05, dir. relator Marcos Barbosa, julgado em 22.10.2007.

Processo Administrativo Sancionador CVM no 12/20113, dir. relator Gustavo Borba, julgado em 24.05.2016.

Processo Administrativo Sancionador CVM n ${ }^{\circ}$ RJ2013/2759, dir. relator Henrique Machado, julgado em 20.02.2018.

Processo Administrativo Sancionador CVM N ${ }^{\circ}$ SP2014/0465, dir. relator Gustavo Machado Gonzalez, julgado em 06.11.2018.

Inquérito Administrativo CVM 20/88, julgado em 17.10.1989.

Recurso CRSFN no 5957, relator André Luiz Dumortout de Mendonça, julgado em fevereiro de 2005.

Recurso CRSFN n 14.400, relator Sérgio Cirpriano, julgado em junho de 2018 . 
TRF da $2^{\mathrm{a}}$ Região, Sétima Turma Especializada, processo $\mathrm{n}^{\mathrm{o}}$ 2004.5101.0140181, rel. des. Reis Friede, julgado em 02.03.2011. 